\title{
Biological Role of Unsaturated Fatty Acid Desaturases in Health and Disease
}

\author{
Aleksandra Czumaj * (D) and Tomasz Śledziński \\ Department of Pharmaceutical Biochemistry, Faculty of Pharmacy, Medical University of Gdansk, Dębinki, \\ 80-211 Gdansk, Poland; tomasz.sledzinski@gumed.edu.pl \\ * Correspondence: aczumaj@gumed.edu.pl
}

Received: 10 December 2019; Accepted: 28 January 2020; Published: 29 January 2020

\begin{abstract}
Polyunsaturated fatty acids (PUFAs) are considered one of the most important components of cells that influence normal development and function of many organisms, both eukaryotes and prokaryotes. Unsaturated fatty acid desaturases play a crucial role in the synthesis of PUFAs, inserting additional unsaturated bonds into the acyl chain. The level of expression and activity of different types of desaturases determines profiles of PUFAs. It is well recognized that qualitative and quantitative changes in the PUFA profile, resulting from alterations in the expression and activity of fatty acid desaturases, are associated with many pathological conditions. Understanding of underlying mechanisms of fatty acid desaturase activity and their functional modification will facilitate the development of novel therapeutic strategies in diseases associated with qualitative and quantitative disorders of PUFA.
\end{abstract}

Keywords: fatty acid desaturase; polyunsaturated fatty acid; desaturation; disease; FADS

\section{Introduction}

Fatty acids (FAs) are essential for the normal functioning of all organisms. FAs are components of plasma membranes, function as energy storage material, and act as signal molecules regulating growth and differentiation of cells, as well as the expression of genes [1,2]. The structure of FAs can be modified by elongation and desaturation. The biological effects of FAs depend on the number of unsaturated bonds in their molecules [3,4].

The enzymes that insert unsaturated bonds to FA molecules are referred to as fatty acid desaturases. These enzymes catalyze the biosynthesis of monounsaturated fatty acids (MUFAs) and polyunsaturated fatty acids (PUFAs) by conversion of single bonds $(C-C)$ into double bonds $(C=C)$ in the acyl chain. Conversion of saturated FAs into MUFAs is catalyzed by stearoyl-CoA desaturase-1 (SCD1), but the role of this enzyme will not be discussed in this review. PUFAs are formed in the reactions catalyzed by another group of desaturases, unsaturated fatty acid desaturases. The type, expression level, and activity of unsaturated fatty acid desaturases determine the qualitative and quantitative composition of PUFA profile. These enzymes are present in all living organisms, but their role in bacteria, fungi, plants, and animals differ considerably.

PUFAs, formed in the reactions catalyzed by unsaturated fatty acid desaturases, are important bioactive compounds that regulate many physiological processes. The most important PUFAs in this context seem to be omega-3 and omega-6 FAs, the names of which derive from the position of the first double bond from the methyl end. The group of omega-3 FAs includes alpha-linolenic acid (ALA, 18:3), eicosapentaenoic acid (EPA, 20:5), and docosahexaenoic acid (DHA, 22:6), whereas linoleic acid (LA, 18:2), gamma-linolenic acid (GLA, 18:3), dihomo-gamma-linolenic acid (DGLA, 20:3), and arachidonic acid (ARA, 20:4) are the examples of omega-6 FAs. PUFAs can produce various biological effects due to their ability to change the composition of plasma membranes, to regulate gene 
transcription, and to modulate cell signaling [5,6]. PUFAs are precursors of various lipid mediators, including pro- and anti-inflammatory eicosanoids and docosanoids. Prostaglandins, prostacyclins, and leukotrienes derived from PUFAs are involved in inflammatory reactions and immune response. ARA is a precursor of pro-inflammatory eicosanoids, whereas EPA and DGLA are substrates for the synthesis of anti-inflammatory eicosanoids. DHA is also a precursor of anti-inflammatory and immunomodulatory docosanoids, such as resolvins and protectins $[7,8]$. Considering their biological functions mentioned above, both omega- 3 and omega- 6 FAs are considered key factors in the prevention of some undesirable bodily reactions, such as autoimmune response. Moreover, PUFAs play a significant role in chronic diseases, including cardiovascular disorders, cancers, and diabetes mellitus $[9,10]$.

In addition to controlling the PUFA content, recent studies have shown that unsaturated fatty acid desaturases play an important role in glycolytic nicotinamide adenine dinucleotide $\left(\mathrm{NAD}^{+}\right)$recycling in the cell and as a consequence, they can be an alternative route for the flow of reducing equivalents generated during glycolysis [11]. Under anaerobic conditions, when mitochondrial respiration is impaired, not only anaerobic glycolysis but also unsaturated fatty acid desaturases can oxidize the reduced form of nicotinamide adenine dinucleotide (NADH) to regenerate the $\mathrm{NAD}^{+}$pool, which can be used by glyceraldehyde 3-phosphate dehydrogenase during glycolysis. Considering the complex function of PUFAs and unsaturated fatty acid desaturases itself (regardless from their products), changes in the expression or activity of fatty acid desaturases may have important consequences for the regulation of many processes taking place in the body, either those associated with basic metabolism or those involved in the development of various pathological conditions. In this review, we focus primarily on unsaturated fatty acid desaturases; we discuss the role of these enzymes, their effect on human health, potential therapeutic applications that have been proposed recently and future research possibilities.

\section{Activity of Unsaturated Fatty Acid Desaturases}

Desaturase genes are widely spread in plant and animal kingdoms [12-14]. Fatty acid desaturases convert MUFAs to PUFAs or insert additional unsaturated bonds into already existing PUFAs, but in some organisms not all of these activities are present (Figure 1). A plethora of various fatty acid desaturases have been identified, each of them inserting the double bond into a unique position. The regional selectivity of desaturases allows them to distinguish between the two ends of the FA acyl chain. A given desaturase always inserts the new double bond between the already existing unsaturated bond and the methyl end (methyl-end desaturase, e.g., delta- 12 or delta- 15 desaturase) or carboxyl end (front-end desaturase, e.g., delta-4, delta-5, delta- 6 desaturase). The name of the given enzyme reflects the position of the acyl chain in which the double bond is inserted. According to a traditional naming convention, an enzyme from this group is referred to as 'delta $X$ desaturase', where $X$ is the number corresponding to the position from the molecule's end at which the double bond is inserted, whereas delta $(\Delta)$ means that the positions are counted from the carboxyl end.

The reaction catalyzed by desaturase is an aerobic process. Aside from the presence of oxygen (as a hydrogen acceptor), reaction requires cytochrome b5 (electron carrier) and NADH-dependent cytochrome b5 reductase. During the first stage of the desaturation process, reduced cytochrome b5 interacts with the non-heme iron active site of the desaturase, which enables the enzyme to react with $\mathrm{O}_{2}$ and a substrate. This results in the activation of hydrogen at the carbon of incipient double bond in substrate. The product of this relatively slow stage is a very short-lived carbon-centered radical $[15,16]$. During the second stage, this transient molecule loses the second hydrogen via rapid disproportionation, which leads to the formation of the final product with a new double bond, along with two molecules of water [17]. 


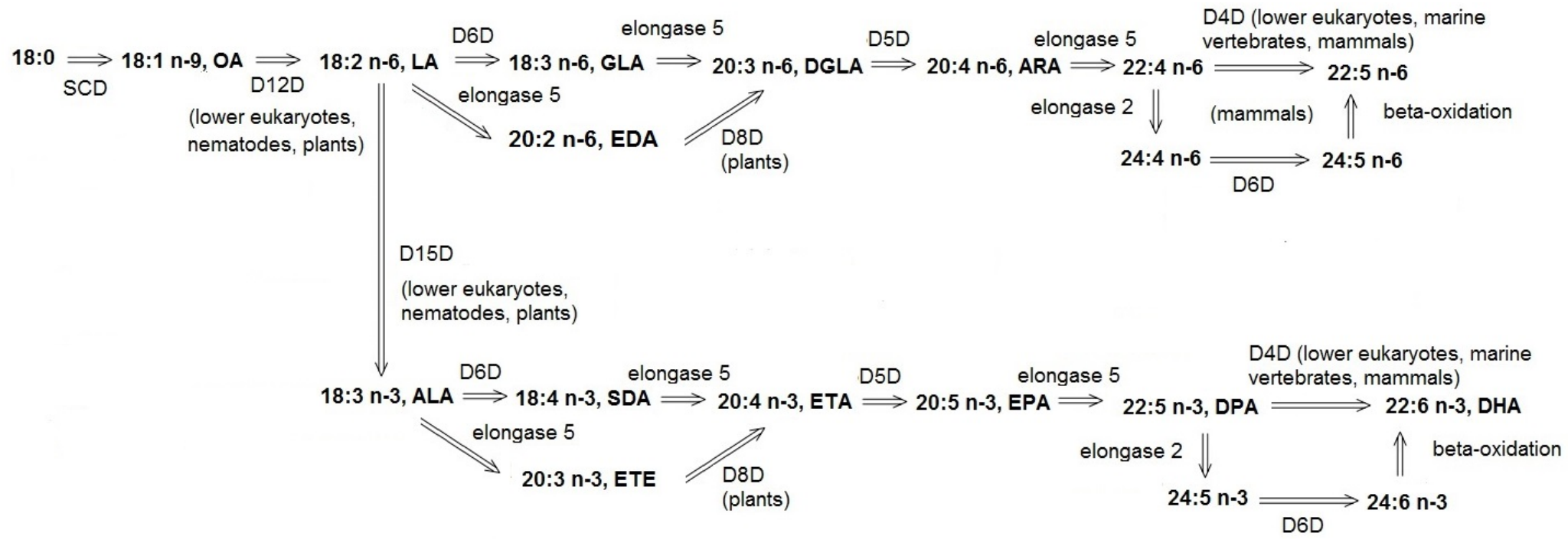

Figure 1. Desaturase-mediated synthesis of polyunsaturated fatty acids (PUFAs). ALA—alpha-linolenic acid, 18:3 n-3, ARA-arachidonic acid, 20:4 n-6, DGLA—dihomo-gamma-linolenic acid, 20:3 n-6, DHA—docosahexaenoic acid, 22:6 n-3, DPA—docosapentaenoic acid, 22:5 n-3, D4D—delta-4 desaturase, D5D—delta-5 desaturase, D6D—delta-6 desaturase, D8D—delta-8 desaturase, D12D—delta-12 desaturase, D15D—delta-15 desaturase, EDA—eicosadienoic acid, 20:2 n-6, ETA—eicosatetraenoic acid, 20:4 n-3, ETE—eicosatrienoic acid, 20:3 n-3, EPA—eicosapentaenoic acid, 20:5 n-3, GLA—gamma-linolenic acid, 18:3 n-6, LA—linoleic acid, 18:2 n-6, OA—oleic acid, 18:1 n-9, SCD—stearoyl-CoA desaturase (delta-9 desaturase), SDA—stearidonic acid, 18:4 n-3. 
Eukaryotic desaturases share similar structural motifs. These enzymes have an N-terminal cytochrome b5 domain, which contains the heme-binding motif, crucial for catalytic activity of desaturases [18,19]. The C-terminal domain contains three histidine motifs with seven histidines (the so-called His box) which are also vital for the catalytic activity. Substitution of histidine with glutamine in the third motif from the C-end is a specific feature of all desaturases that insert a double bond between the already existing bond and carboxyl end. Separation of the first and second histidine motif by a long histidine fragment, aside from fatty acid desaturases, is also observed in aldehyde hydroxylases and carboxylases [20,21].

The most well-known examples of fatty acid desaturases are delta-6 desaturase (D6D), delta-5 desaturase (D5D), delta-12 desaturase (D12D), and delta-15 desaturase (D15D). D6D catalyzes the insertion of the double bond between sixth and seventh carbon from the carboxyl end. Reaction of D6D is the rate-limiting step in the formation of GLA from LA and stearidonic acid (SDA, 18:4 n-3) from ALA [22]. D6D can use at least two other substrates, tetracosatetraenoic acid (24:4 n-6) and tetracosapentaenoic acid (24:5 n-3), converting them into tetracosapentaenoic acid (24:5 n-6) and tetracosahexaenoic acid (24:6 n-3), respectively. Aside from the activity of delta-6 desaturase, this enzyme can also show other desaturase activities, e.g., synthesize DGLA and eicosatetraenoic acid (ETA, 20:4 n-3) from eicosadienoic acid (EDA, 20:2 n-6) and eicosatetraenoic acid (ETE, 20:3 n-3), respectively $[23,24]$. Moreover, D6D is responsible for the synthesis of sapienic acid, the most abundant FA of human sebum, catalyzing desaturation of 16:0 to 16:1 n-10. The latter reaction is a unique example of this enzyme activity because it leads to the synthesis of MUFA, and this reaction occurs exclusively in sebaceous glands [25]. D5D inserts double bond at the fifth position from the carboxyl end. This enzyme is primarily involved in the synthesis of ARA and EPA, using DGLA and ETA, respectively, as the substrates [26]. Other acids, such as 20:3 n-3 and 20:2 n-6, can also serve as the substrates for D5D. Moreover, some isoforms of D5D can catalyze the synthesis of atypical products, such as non-methylene-interrupted fatty acids (FA where double bound are interrupted with group other than methylene), e.g., 18:3 $\Delta 5,9,12$ and 20:4 $\Delta 5,11,14,17$ [19,21,27,28]. D12D and D15D are the key enzymes involved in the synthesis of omega-3 and omega-6 FAs. D12D is responsible for the conversion of oleic acid (OA, 18:1 n-9) to LA, and D15D desaturates LA to ALA [29]. These enzymes are not expressed in all mammals, including humans; as a result, they cannot synthesize LA and ALA de novo and need to obtain these essential FAs from the diet. Delta-12 and/or delta-15 desaturases are expressed in lower eukaryotes and most plants, as well as in some animals, such as cockroaches, house crickets, and parasitic wasps [30-32].

Regulation of the expression and activity of unsaturated fatty acid desaturases is a very complex biochemical phenomenon. Dietary PUFA intake and transcriptional regulation are well-recognized determinates of unsaturated fatty acid desaturases activity. Many studies proved that dietary FA can influence gene expression of unsaturated fatty acid desaturases [33,34]. Both D5D and D6D expression were reduced by PUFAs in multiple experimental models, ranging from cell lines cultured in vitro and treated with different PUFAs to animals fed with PUFA-enriched diets (including grouper larvae, European sea bass, mice, piglets, and baboons) [35-38]. Unsaturated fatty acid desaturases gene expression is also regulated by insulin and gonadal hormones [39-41]. Several transcription factor binding site motifs were identified in promoters regions of unsaturated fatty acid desaturases, including nuclear factor $\mathrm{Y}(\mathrm{NF}-\mathrm{Y}), \mathrm{CCAAT}$ enhancer binding protein (C/EBP), sterol regulatory element (SRE), nuclear factor 1 (NF-1), stimulatory protein 1 (Sp1), activated protein 1 (AP1), hepatocyte nuclear factor $4 \alpha(\mathrm{HNF} 4 \alpha)$, and peroxisome proliferator activated receptor $\gamma(\operatorname{PPAR} \gamma)$ [42-44]. Epigenetic alterations (i.e., methylation of DNA) may also contribute to changes in desaturase activity $[45,46]$. Furthermore, recent findings suggest that D5D and D6D activity can change in response to the cytosolic $\mathrm{NAD}^{+} / \mathrm{NADH}$ ratio. The decreased cytosolic $\mathrm{NAD}^{+} / \mathrm{NADH}$ ratio (for example, as a result of inhibition of aerobic cellular respiration) increases the activity of unsaturated fatty acid desaturases, without change in mRNA or protein levels [11]. 


\section{Role of Unsaturated Fatty Acid Desaturases}

The activity of desaturases determines, together with dietary FA intake, the qualitative and quantitative composition of unsaturated FAs. Products of these enzymes are essential components of all biological systems. The exact role of desaturases depends on the organism in which they are expressed.

\subsection{Role of Unsaturated Fatty Acid Desaturases in Microorganisms}

Firstly, the desaturases genes were discovered, and their functions were recognized in microorganisms. For example, the first D6D gene was cloned from cyanobacterium Synechocystis, the first D5D gene was cloned from fungus Mortierella alpina, and the first D8D gene was cloned from the protist Euglena gracilis. Up to now, microorganisms remain a subject of interest in many researches on the structure, function, and activity of unsaturated fatty acid desaturases [47-49].

In bacteria, changes in the PUFA composition in plasma membranes can be helpful in the adjustment to unfavorable environmental conditions. These organisms can change the activity of desaturases to adapt the PUFA content to changing temperature, $\mathrm{pH}$, and atmospheric pressure to maintain appropriate fluidity of plasma membranes. Long-chain PUFAs are detected in the largest amount in bacteria inhabiting cold marine environments, such as polar regions or deep seas. Transfer of such bacteria into a warmer environment has resulted in changes in expression of desaturases genes and in a decrease in the PUFA content in membrane phospholipids [50-53].

PUFAs in microorganisms usually have 16 or 18 carbons, nevertheless, some microorganisms were shown to synthesize ARA, EPA, and DHA [54]. Nowadays primary sources of EPA and DHA in our diet are marine water fish species. However, their availability is limited due to catch limits implemented to prevent resource depletion. Hence, the use of microorganisms expressing specific homologous or heterologous unsaturated fatty acid desaturases capable of synthesizing EPA and DHA seems to be a promising alternative source of omega-3 FAs [54-57]. Current commercially used microorganisms to produce n-3 PUFA, such as Crypthecodinium cohnii, Schizochytrium sp., or Nannochloropsis sp., are the result of intensive screening and selective breeding procedures. Genetic engineering of unsaturated fatty acid desaturases in microorganisms opens up new possibilities to maximize the efficiency of upstream and downstream processing [58-61].

\subsection{Role of Unsaturated Fatty Acid Desaturases in Plants}

FA composition is crucial for the growth and vegetation of plants [62]. FA desaturation is a key factor determining the tolerance of plants to various environmental stressors [63]. Enhanced accumulation of PUFAs, due to changes in desaturases gene expression level, is postulated to facilitate cold adaptation, maintaining normal fluidity and integrity of plasma membranes [64]. For example, in many plants the expression of FAD8 gene (genes encoding fatty acid desaturases in plants belong to the FAD family) is strongly induced by low temperatures (product of this gene catalyzed by the conversion of diene fatty acids to triene fatty acids), [64,65]. However, excessive accumulation of PUFAs may also exacerbate a thermal injury [66]. Transgenic tobacco transformed with FAD7 gene showed greater resistance to cold, whereas the plants with silenced FAD7 contained less trienoic fatty acids and showed better tolerance to high temperatures than the wildtype plants [67,68]. Furthermore, FAD2 and FAD6 genes in seedlings were shown to be activated by salt and osmotic stress [69]. Mutants with FAD2 deficiency accumulated more sodium ions $(\mathrm{Na}+)^{+}$in the cytoplasm of root cells and were highly sensitive to salt stress during seed germination and early seedling growth [70].

The activity of various fatty acid desaturases is also crucial in the context of nutritional properties of edible oils, as these enzymes determine the contents of individual PUFAs in the final product [71,72]. Progress in genetic engineering opened a perspective for modification of fatty acid desaturases to enrich cultivated plants in particularly desirable FAs. Many research groups obtained transgenic plants that can synthesize and accumulate selected FAs, such as OA, EPA, DHA, and SDA [19,73-77]. For example, expression of borage (Borago officinalis) D6D in oilseed crops contributed to increase in SDA levels up to 
$20 \%$ of all FAs present in these plants [73,74]. High levels of EPA were reported in Ethiopian mustard (Brassica carinata) after its transformation with the fungal D5D gene [78]. Few research groups were able to produce DHA in plants by using the D4D gene from microorganisms [79-82]. A higher specific PUFA consumption is recommended by doctors and nutritionists in several diseases, such as cardiovascular diseases, diabetes, and inflammatory disorders. However, the efficacy, quality, and safety of PUFA supplements available on the market are questionable because they are beyond any pharmaceutical control [83-85]. Several studies conducted in geographically diverse locations have shown that vegans and vegetarians have lower levels of DHA and EPA in the serum compared to omnivores [86-88]. Therefore, the use of plants with modified fatty acid desaturases seems to be a promising alternative for dietary n-3 PUFA consumption. This can be especially important for vegan and vegetarian mothers during breastfeeding.

\subsection{Role of Unsaturated Fatty Acid Desaturases in Humans and Other Mammals}

Our unsaturated fatty acid desaturases activity and our PUFA profile is a consequence of diet and genetic makeup. Even one single nucleotide polymorphisms (SNPs) in FADS genes (mammalian desaturase genes that belong to the FADS family) were shown to be associated with altered activity of fatty acid desaturases and significant changes in plasma lipid profile [89-93]. People with high dietary intake of ALA who carried one or two altered FADS1 alleles (the so-called rs174546 variant), presented with lower concentrations of total cholesterol and non-HDL cholesterol than those with other allelic variants and the same intake of this FA (FADS1 encodes D5D) [94]. An exploratory study from Australia reports that FADS1 genotype can also alter the effects of long-chain PUFA supplementation. Only children with certain FADS1 SNPs benefit from fish oil supplementation [95]. Recent studies of the mouse FADS2 gene (encodes D6D) demonstrated that even one non-synonymous SNP can alter properties of the enzyme. SNP A $\rightarrow \mathrm{G}$ was associated with the change of amino acid in the region responsible for iron binding. The presence of $G$ allele seems to be associated with lower activity of the desaturase since mice carrying this allele had higher levels of LA and ALA and lower levels of ARA, EPA, and DHA. Moreover, the G allele was shown to be more common in mice with higher basal metabolic rate [96]. The protein encoded by the third mammalian fatty acid desaturase gene, $F A D S 3$, has yet not been ascribed any specific function. Expression of FADS3 was found in many human organs. Surprisingly, recent in vitro studies demonstrated that the product of FADS3 in rat encodes the enzyme which can catalyze delta-13 desaturation of trans-vaccenic acid (VA, trans-11 18:1) to trans-11, cis-13 conjugated linoleic acid (CLA; trans-11, cis-13 18:2). Hence, FADS3 might be the first gene encoding methyl-end desaturase in mammals, but this concept still has not been confirmed in vivo $[97,98]$. What is interesting, some studies have shown that unsaturated fatty acid desaturases activity resulting from genetic variants of $F A D S$ genes can be masked. Alterations with the gene-related PUFA profile was only observed in normal weight women, whereas overweight/obese women (with a BMI $\geq 25$ ) are less affected by FADS genetic variants in this regard [99]. Exploration of gene-BMI interactions in the general population or male subpopulation is still needed.

Fatty acid desaturases seem to exert a variable effect on human health. This functional link results from a relationship between specific polymorphisms of desaturase genes and various metabolic phenotypes (Table 1) [100]. Many studies demonstrated a relationship between the activity of these enzymes and various complex diseases, such as coronary artery disease (CAD). Among patients with $\mathrm{CAD}$, the activity of D6D was higher in comparison to healthy subjects. Moreover, specific SNP can alter the probability of CAD occurrence. For example, SNP in position rs174537G/T is associated with a higher risk of CAD. Variant rs174537T is associated with a lower risk of CAD, while variant rs174537G is more common in CAD patients [101-103]. Fortunately, there is an evidence that appropriate modification of PUFA intake from the diet can prevent the unfavorable effects of FADS polymorphism [104]. 
Table 1. Selected traits associated with unsaturated fatty acid desaturases genetic variants—('?'- SNP variants not specified in the study).

\begin{tabular}{|c|c|c|c|c|c|}
\hline Type of Desaturases & SNP Variants & Associated Trait & Nature of The Change & Tested Population & Reference \\
\hline \multirow{13}{*}{ FADS1 } & rs174551-? & Alanine transaminase levels & Higher serum ALT level & East Asian & [105] \\
\hline & rs174541-C & Bipolar disorder & Specific variant more common in subjects with the disease & East Asian, European & {$[106,107]$} \\
\hline & rs174556-T & Breast milk fatty acid composition & Higher breast milk AA level & South Asian & [108] \\
\hline & rs174549-A & $\begin{array}{c}\text { Cancer (Laryngeal } \\
\text { squamous cell carcinoma) }\end{array}$ & Specific variant more common in subjects with the disease & East Asian & [109] \\
\hline & $\begin{array}{l}\text { rs174564-G } \\
\text { rs174546-T } \\
\text { rs174549-A } \\
\text { rs174547-C }\end{array}$ & Cardiology traits & $\begin{array}{c}\text { Higher pulse } \\
\text { Shorter QT interval } \\
\text { Increased heart rate } \\
\text { Lower resting heart rate }\end{array}$ & $\begin{array}{c}\text { European, African, } \\
\text { Hispanic/Latin American, } \\
\text { Asian unspecified, Native American }\end{array}$ & [110-113] \\
\hline & $\begin{array}{l}\text { rs174546-C } \\
\text { rs174550-T } \\
\text { rs174551T } \\
\text { rs174547-C } \\
\text { rs174546-T }\end{array}$ & Cholesterol & $\begin{array}{l}\text { Higher level of HDL } \\
\text { Higher total cholesterol } \\
\text { Higher level of LDL } \\
\text { Lover level of HDL } \\
\text { Lower total cholesterol } \\
\text { Lower level of LDL }\end{array}$ & $\begin{array}{l}\text { European, East Asian, South Asian, } \\
\text { Hispanic/Latin American, African } \\
\text { American/Afro-Caribbean, Oceanian, } \\
\text { Native American }\end{array}$ & [114-127] \\
\hline & rs174550-T & Fasting blood glucose & Increased fasting blood glucose & $\begin{array}{c}\text { Hispanic/Latin American, } \\
\text { African American/Afro-Caribbean, } \\
\text { East Asian, Oceanian, } \\
\text { Native American, European }\end{array}$ & {$[123,128-130]$} \\
\hline & $\begin{array}{l}\text { rs174548-G } \\
\text { rs174549-A }\end{array}$ & Fatty acid desaturase activity & $\begin{array}{l}\text { Not specified } \\
\text { Lower activity }\end{array}$ & East Asian, European & {$[91,131,132]$} \\
\hline & $\begin{array}{l}\text { rs174549-A } \\
\text { rs174548-Grs174555-C } \\
\text { rs174548-G }\end{array}$ & Hematology traits & $\begin{array}{c}\text { Higher monocytes \% } \\
\text { Lower white blood cell count } \\
\text { Higher platelet count, } \\
\text { Sum eosinophil basophil counts } \\
\text { Lower granulocytes count } \\
\text { Lower red cel distribution width }\end{array}$ & European, East Asian & [133-137] \\
\hline & rs174547-T & Height & Unspecified & East Asian, European & {$[133,138]$} \\
\hline & $\begin{array}{l}\text { rs174550-T } \\
\text { rs174547-T }\end{array}$ & Plasman-3 polyunsaturated fatty acid level & $\begin{array}{l}\text { Higher EPA level } \\
\text { Lower ALA level } \\
\text { Higher DPA level }\end{array}$ & European & [139] \\
\hline & $\begin{array}{l}\text { rs174550-T } \\
\text { rs174547-C } \\
\text { rs174546-T }\end{array}$ & Plasman-6 polyunsaturated fatty acid levels & $\begin{array}{c}\text { Higher adrenic acid } \\
\text { Lower ARA level } \\
\text { Lower DGLA level }\end{array}$ & European, East Asian & {$[131,140]$} \\
\hline & rs174546-T & Triglyceride levels & Higher TG level & $\begin{array}{c}\text { European, Hispanic/Latin American, } \\
\text { African American or Afro-Caribbean, } \\
\text { South Asian, East Asian, Oceanian, } \\
\text { NativeAmerican } \\
\end{array}$ & {$[105,115-121,123,124]$} \\
\hline
\end{tabular}


Table 1. Cont

\begin{tabular}{|c|c|c|c|c|c|}
\hline Type of Desaturases & SNP Variants & Associated Trait & Nature of The Change & Tested Population & Reference \\
\hline \multirow{18}{*}{ FADS2 } & $\begin{array}{l}\text { rs174566-A } \\
\text { rs174621-G }\end{array}$ & Asthma & Specific variant more common in subjects with the disease & European & [141] \\
\hline & $\begin{array}{l}\text { rs174592-G } \\
\text { rs174581-A }\end{array}$ & Balding (type 1, male-pattern baldness) & Specific variant more common in subjects with the disease & European & {$[133,142,143]$} \\
\hline & $\begin{array}{l}\text { rs12226877-A } \\
\text { rs28456-G } \\
\text { rs174576-A }\end{array}$ & Bipolar disorder & Specific variant more common in subjects with the disease & East Asian, European & {$[106,107]$} \\
\hline & $\begin{array}{l}\text { rs174594-A } \\
\text { rs1535-A } \\
\text { rs2072113-C }\end{array}$ & $\begin{array}{l}\text { Cancer (Laryngeal squamous cell carcinoma, } \\
\text { Colorectal cancer, lung cancer) }\end{array}$ & Specific variant more common in subjects with the disease & $\begin{array}{l}\text { East Asian, European, } \\
\text { African American/Afro-Caribbean }\end{array}$ & {$[109,144-147]$} \\
\hline & $\begin{array}{l}\text { rs174577-A } \\
\text { rs174564-G } \\
\text { rs174583-T } \\
\text { rs174577-? }\end{array}$ & Cardiology traits & $\begin{array}{l}\text { Shorter P-wave duration } \\
\text { Higher pulse pressure } \\
\text { Shorter QT interval } \\
\text { Shorter QRS duration }\end{array}$ & South Asian, European & [111-113,148-150] \\
\hline & $\begin{array}{l}\text { rs174570-G } \\
\text { rs174577-C } \\
\text { rs174566-G } \\
\text { rs174570-T }\end{array}$ & Cholesterol levels & $\begin{array}{l}\text { Higher total cholesterol, } \\
\text { HDL, LDL levels } \\
\text { Higher HDL level } \\
\text { Higher LDL level } \\
\text { Lower LDL level }\end{array}$ & $\begin{array}{c}\text { European, Hispanic/Latin American, } \\
\text { African American or Afro-Caribbean, } \\
\text { East Asian }\end{array}$ & {$[114-116,118-122,125,151,152]$} \\
\hline & $\begin{array}{l}\text { rs174583-T } \\
\text { rs174577-A }\end{array}$ & $\begin{array}{c}\text { Comprehensive strength } \\
\text { and appendicular lean mass }\end{array}$ & Higher comprehensive strength and appendicular lean mass & East Asian & [153] \\
\hline & $\begin{array}{l}\text { rs174566-G } \\
\text { rs2072113-T }\end{array}$ & Fatty acid desaturase activity & Decrease activity & European, East Asian & {$[91,131,132]$} \\
\hline & rs174601-T & Gondoic acid (20:1 n-9) levels & Higher FA level & East Asian, European & [154] \\
\hline & $\begin{array}{l}\text { rs968567-T } \\
\text { rs2727271-? } \\
\text { rs174570-C } \\
\text { rs174577-A } \\
\text { rs61897795-G } \\
\text { rs2727271-T }\end{array}$ & Hematology traits & $\begin{array}{c}\text { Higher IgA level } \\
\text { Lower albumin-globulin ratio } \\
\text { Higher glycated hemoglobin level } \\
\text { Higher transferrin level } \\
\text { Lower neutrophil count } \\
\text { Higher non-albumin protein levels }\end{array}$ & East Asian, South Asian, European & {$[105,133,134,136,155-157]$} \\
\hline & rs174574-A & Heel bone mineral density & Higher bone mineral density & European & {$[158,159]$} \\
\hline & rs174599-? & Hypothyroidism & Lower thyroid hormones & European & [133] \\
\hline & rs4246215-T & Inflammatory bowel disease & Specific variant more common in subjects with the disease & European & {$[160,161]$} \\
\hline & $\begin{array}{l}\text { rs174574-A } \\
\text { rs1535-A }\end{array}$ & Plasma n-3 PUFA levels & $\begin{array}{c}\text { Lower level of EPA, } \\
\text { Lower ALA level } \\
\text { Higher DPA }\end{array}$ & European & [139] \\
\hline & $\begin{array}{l}\text { rs174577-C } \\
\text { rs2727270-T } \\
\text { rs174578-T }\end{array}$ & Plasma n-6 PUFA levels & $\begin{array}{l}\text { Higher ARA level } \\
\text { Higher LA level } \\
\text { Lower LA level }\end{array}$ & European, East Asian & {$[131,140]$} \\
\hline & rs968567-C & Rheumatoid arthritis & Specific variant more common in subjects with the disease & $\begin{array}{c}\text { European, East Asian, } \\
\text { African American Afro-Caribbean }\end{array}$ & {$[162,163]$} \\
\hline & rs174560-C & Sleep duration & Longer habitual sleep duration & European & [164] \\
\hline & $\begin{array}{l}\text { rs174564-G } \\
\text { rs174577-C }\end{array}$ & Triglyceride levels & Lower TG level & $\begin{array}{l}\text { European, Hispanic/Latin American, } \\
\text { African American/Afro-Caribbean, } \\
\text { South Asian, East Asian }\end{array}$ & {$[105,115-121,123,124]$} \\
\hline
\end{tabular}


Table 1. Cont.

\begin{tabular}{cccccc}
\hline Type of Desaturases & SNP Variants & Associated Trait & Nature of The Change & Reference & Tested Population \\
\hline & rs1000778-A & Sphingolipid levels & Lower sphingolipids level & European \\
\cline { 2 - 6 } FADS3 & $\begin{array}{c}\text { rs174468-A } \\
\text { rs174448-A }\end{array}$ & Plasma n-3 PUFA levels & $\begin{array}{c}\text { Higher level of ALA } \\
\text { Lower level of DPA, EPA }\end{array}$ & European \\
\cline { 2 - 6 } & $\begin{array}{c}\text { rs174449-A } \\
\text { rs174448-A }\end{array}$ & Trans fatty acid levels & Higher concentrations of cis/trans-18:2 & $\begin{array}{c}\text { European, African } \\
\text { American/Afro-Caribbean, } \\
\text { East Asian, Hispani/Latin American }\end{array}$ \\
\hline
\end{tabular}


Since n-3 PUFA are considered as anti-inflammatory substances, altered PUFA metabolism facilitates the chronic inflammation observed in Crohn's disease (CD). Data from the genome-wide association study point to a few SNP in FADS genes associated with CD risk $[167,168]$. Analysis of D6D in mesenteric adipose tissue biopsies (abnormal mesenteric adipose tissue is the hallmark of CD) shows a lower level of D6D in CD specimens than in normal tissue at both mRNA and protein level [169]. However, the activity of D6D, calculated as enzyme activity indexes based on the fatty acid concentration in plasma, was significantly higher in the CD patients than in the healthy volunteers [170]. Moreover, studies suggest that patients with CD benefit from varying degrees of n-3 PUFA supplementations [171]. Lack of consistency across studies may be explained by the presence of gene-diet interactions. For example, patients with specific FADS variants associated with higher endogenous production of n-6 PUFA have a greater risk of developing CD even with lower dietary intake of n-6 PUFA, so they can benefit from n-3 PUFA supplementation, whereas patients with FADS variants associated with a lower endogenous production of n-3 PUFA, even with high dietary PUFA intake, still tends to have a lower n-3 PUFA level, so they benefit less from n-3 PUFA supplementations than patients with other FADS variants $[168,172,173]$. This suggests that in the future, a more personalized approach is needed.

Many studies conducted in humans and mice showed correlations between the activities of delta-5 and delta- 6 desaturases and metabolic syndrome, insulin resistance, and obesity. They reported that there is a strong positive correlation between D6D activity and the risk of these conditions, whereas the activity of D5D is inversely related to metabolic syndrome, insulin resistance, and obesity (no genetic backgrounds were investigated in these studies) [174-176]. Comparative genetic analysis of persons with insulin resistance and normal sensitivity to insulin demonstrated downregulation of D5D expression in adipose tissue and muscles of the former group (no activity measurements were made in this study) [177]. The problem is even more complicated if we take into consideration the fact that certain SNP can modulate desaturases activity. Some studies from Japanese populations show that some variant of FADS1 (SNP rs174550) was significantly associated with an increased risk of type 2 diabetes [178]. Interestingly, the same SNP in the European population was associated with the lower fasting plasma glucose level in a normal physiological range, but not with pathological glucose levels [179]. Data from multiple experiments on mice suggest that the development of selective desaturases inhibitors can be beneficial in the treatment of human diabetes, obesity, and atherosclerotic cardiovascular disease [180-182]. Mice with D6D knockdown developed resistance against high-fat diet induced obesity, so maybe some metabolic benefits for obese people can be gained with D6D inhibitors [183]. Since obesity is considered as a chronic low-grade inflammation state, D5D inhibitors can be also beneficial. Potential D5D inhibitor can increase DGLA level (precursor of anti-inflammatory eicosanoids) and decrease AA level (precursor to pro-inflammatory eicosanoids). Insulin resistance is a complicated condition and several factors including genetic makeup, lifestyle, and diet contribute to its development. Considering them separately may lead to inconsistencies across different studies, such as in case of studies on the effectiveness of PUFA supplementation. Studies have shown, that n-3 PUFA supplementation can be effective in prevention or reversion of insulin resistance, but only together with reducing the intake of saturated FA, trans-FA, and n-6 PUFA. Supplementation of n-6 PUFA may also decrease insulin resistance but only if n-6 PUFA replaces SFA, trans-FA, or sucrose. Replacing n-3 PUFA with n-6 PUFA in the diet can worsen insulin resistance [184-186]. n-3 PUFA may prevent insulin resistance by a number of different mechanisms, including regulation of inflammation, modulation of adiponectin and leptin secretion, and influencing the expression of several genes involved in carbohydrate and lipid metabolism [187-189]. It seems that associations between desaturases and complex metabolic conditions such as metabolic syndrome, insulin resistance, and obesity are still not fully understood and some mechanisms still remain elusive.

Patients with non-alcoholic fatty liver disease (NAFLD) present a higher level of free FA in the serum and altered profile of FA in comparison to healthy subjects, including higher total SFA, higher total MUFA, lower total PUFA [190,191]. Available evidence shows that altered activity of fatty acid desaturases is one of the risk factors of NAFLD. Patients with NAFLD were shown to 
present with a higher activity of D6D and lower activity of D5D than healthy volunteers [192-194]. A similar observation was made in the case of pediatric non-alcoholic liver disease [195]. Differences in activity of desaturases are often connected to naturally existing genetic variations of those genes [196]. Better understanding of the connection between locus polymorphism and level of functional enzyme can result in the personalized treatment strategy for NAFLD in the near future. A pilot study from 2018 has shown that NAFLD patients with alleles connected to a low D5D activity benefit more from n-3 PUFA supplementation (significant reduction in steatosis, fibrosis, ballooning, and NAFLD activity score) than patients with others SNP variants [195]. So far, SNPs in patatin-like phospholipase domain-containing protein 3 (PNPLA3) and transmembrane 6 superfamily member 2 (TM6SF2) regions have been identified and validated in large cohorts of patients as a biomarker for NAFLD risk. Maybe in the near future the SNPs in FADS1 will be the third biomarker for NAFLD but some large-scale research is still needed $[197,198]$. However, the situation is complicated by the fact that in NAFLD, as well as, in CAD disturbances in unsaturated fatty acid desaturases are observed and NAFLD is often accompanied by CAD. What is more, CAD is one of the leading causes of death in this group of patients. Nevertheless, there is almost no research on the associations among NAFLD, CAD, and FADS polymorphism [199]. A deeper understanding of FADS SNP in the context of NAFLD with CAD is essential if we want to use a genetic background for early diagnosis and prevention.

Unsaturated fatty acid desaturases also play a significant role in carcinogenesis, including cancer cell survival, metastasis, and drug resistance [200,201]. Genome-wide association study in East Asians population identifies a loci map to FADS1 and FADS2 genes as associated with colorectal cancer and laryngeal squamous cell carcinoma risk $[109,202]$. Unfortunately, there is no information on this matter from populations from other continents, so it is not clear if this can be treated as a universal prediction marker. Moreover, in patients with malignant melanoma, breast, brain and lung malignancies, expression and activity of D6D in cancer tissues turned out to be higher than in adjacent normal tissues [203,204]. It cannot be excluded that this is a common feature of all malignant neoplasms [205]. In animal studies, inhibition of delta-6 desaturase (both through knockdown and via RNAi) effectively prevented cancer growth. Since D6D is an enzyme catalyzing the rate-limiting step of AA synthesis, its activity is crucial for the production of pro-inflammatory eicosanoids, downstream metabolites of AA, such as prostaglandins, leukotrienes, and epoxy-eicosatrienes. Hence, it seems logical that inhibition of the principal metabolite (AA) formation might be a more effective way to reduce the synthesis of pro-inflammatory eicosanoids than blocking each specific pathway (i.e., cyclooxygenase, lipoxygenase, and cytochrome P450 epoxygenase pathway), separately [206]. Reduced unsaturated fatty acid desaturases activity can have an anti-proliferative effect not only because of reduced eicosanoid availability for cell signaling. Another possibility is the altered cytosolic $\mathrm{NAD}^{+} / \mathrm{NADH}$ ratio, which can modulate glycolysis and lactate fermentation-two important sources of respiratory fuel in cancer cells [207]. Studies have shown that transient knockdown of D5D and D6D in cells cultured in vitro resulted in changes in the reactive oxygen species (ROS) level, pyruvate consumption, and cell proliferation [11]. However, further studies are required to resolve whether unsaturated fatty acid desaturases-mediated $\mathrm{NAD}^{+} / \mathrm{NADH}$ ratio play an important role in the Warburg effect in cancer cells. Taking all information together, fatty acid desaturation can be a new metabolic marker and therapeutic target in certain types of cancer. However, according to the authors' knowledge, no FADS1 or FADS2 inhibitors in cancer treatment are undergoing clinical trials.

Fatty acid desaturases also play an important role during pregnancy and breastfeeding. Maternal levels of ARA, EPA, and DHA influence the amount of these acids delivered to the fetus directly or provided with maternal milk after birth. Hence, desaturase activity has an impact on the qualitative and quantitative composition of n-3 and n-6 FAs delivered to the child. FAs, among them ARA, $\mathrm{EPA}$, and DHA, play a key role in growth, development of neurons, and functioning of the immune system in infants [108,180,208-210]. Moreover, the development of cognitive function and intellectual development of the child may be determined by a unique composition of FAs contained in maternal milk [211,212]. Interestingly, few studies also mention a relationship between breast milk fatty acids 
composition and postnatal HIV-1 transmission. ALA can be elongated to create ETE or desaturated to create SDA. When D6D is less active than elongase 5 the amount of ETE in breast milk increases. A higher concentration of ETE was associated with a lower risk of HIV-1 transmission [213]. Unfortunately, a large prospective cohort study is still lacking in this matter.

FAs, especially n-3, can modulate behavior and cognitive function. Animals maintained on a diet excluding or restricting substrates for fatty acid desaturases showed greater locomotor hyperactivity and worse cognitive skills. It was observed that children with specific SNPs in FADS genes (so called DHA-increasing cluster) score more in personal and social skills questionnaire [214]. Moreover, studies demonstrated a link between the variability of nucleotide sequences within desaturase encoding genes and the incidence of attention-deficit hyperactivity disorder (ADHD) [215].

The type of FAs contained in membrane phospholipids may modulate a broad range of biological mechanisms and pathways in the brain, including neurons, glial cells, and endothelial cells integrity and survival, neurotransmission (dopaminergic, serotonergic, glutamatergic, and cholinergic), and neuroinflammation, and [216-218]. PUFAs, especially ARA and DHA, are the major constituents of the neuronal membranes. However, the cause and effect relationship between mental disorders and unsaturated fatty acid desaturases is still unclear. Patients with neuropsychiatric disorders, such as bipolar affective disorders and schizophrenia often present overexpression and increased activity of D6D and at the same time, the levels of n-3 PUFA (DPA, DHA) and n-6 PUFA (EDA, ARA, 22:4 n-6) in neuronal membrane phospholipids were decreased [219-221]. Evidence from in vitro animal and clinical studies suggest that long-term treatment with risperidone (an antipsychotic drug) upregulate the expression and activity of multiple lipogenic genes, including D6D. Interestingly, some studies in animal models suggest that prenatal dietary PUFA deficiency (especially ARA and DHA) may affect early neurodevelopment of the offspring and thereby predispose to the development of schizophrenia [222]. Mice that had experienced gestational and early postnatal dietary ARA and DHA deprivation have shown schizophrenia-like phenotypes at adulthood (lowered levels of motivation, depressive symptoms, and impaired cognitive functions). Since the PUFA profile can be determined both by dietary PUFA intake and desaturase activity, it seems reasonable to assume that maternal activity of desaturases may also play a role in the risk of schizophrenia in offspring. A few studies on rats from the late 1970s and early 1980s mentioned changes in maternal, fetal and pups D5D and D6D activities in response to mothers' low essential FA diet, nevertheless, until this day there are no studies on the relationship between mothers' unsaturated fatty acid desaturases (activity and/or genetic variants) and schizophrenia risk in the offspring $[223,224]$. Furthermore, a relatively small number of studies have examined the therapeutic utility of PUFA supplementation in schizophrenia and none of them mentioned the potential use of FADS inhibitors. Moreover, results of these studies are inconsistent. Observed effects of PUFA supplementation vary from a significant increase in severity of schizophrenia symptoms, through no major effect on symptoms severity to decrease the intensity of symptoms and improve the level of patients functioning [225-227].

\section{Conclusions}

Desaturation of FAs plays a key role in the biosynthesis of lipids. In addition to dietary PUFA intake, the activity of fatty acid desaturases is one of the main determinants of the qualitative and quantitative profile of PUFAs. Changes in the PUFA profile may be either beneficial (e.g., facilitate survival under unfavorable environmental conditions) or harmful, resulting in the development of various pathologies. Further research on fatty acid desaturases will provide a better insight into the metabolic effect of the PUFA profile on human health. Understanding of these relationships might contribute to the development of novel therapeutic strategies based on modifications of fatty acid desaturase activities.

Author Contributions: Conceptualization A.C.; formal analysis, T.S.; writing—original draft preparation, A.C.; writing-review and editing, A.C. and T.S.; supervision, T.S. All authors have read and agreed to the published version of the manuscript. 
Funding: This research was supported by the National Science Centre of Poland (grant no. NCN 2016/22/E/ NZ4/00665). Publication of the article was supported by the project POWR.03.02.00-00-I026/17-00 co-financed by the European Union through the European Social Fund under the Operational Programme Knowledge Education Development 2014-2020.

Conflicts of Interest: The authors declare no conflict of interest. The funders had no role in the writing of the manuscript.

$\begin{array}{ll}\text { Abbreviations } \\ \text { ADHD } & \text { Attention-Deficit Hyperactivity Disorder } \\ \text { ALA } & \text { alpha-linolenic acid, 18:3 n-3 } \\ \text { ARA } & \text { arachidonic acid, 20:4 n-6 } \\ \text { CAD } & \text { coronary artery disease } \\ \text { CD } & \text { Crohn's disease } \\ \text { CLA } & \text { conjugated linoleic acid, trans-11, cis-13 18:2 } \\ \text { D5D } & \text { delta-5 desaturase } \\ \text { D6D } & \text { delta-6 desaturase } \\ \text { D12D } & \text { delta-12 desaturase } \\ \text { D15D } & \text { delta-15 desaturase } \\ \text { DGLA } & \text { dihomo-gamma-linolenic acid, 20:3 n-6 } \\ \text { DHA } & \text { docosahexaenoic acid, 22:6 n-3 } \\ \text { DPA } & \text { docosapentaenoic acid, 22:5 n-3 } \\ \text { EDA } & \text { eicosadienoic acid, 20:2 n-6 } \\ \text { ETA } & \text { eicosatetraenoic acid, 20:4 n-3 } \\ \text { ETE } & \text { eicosatrienoic acid, 20:3 n-3 } \\ \text { EPA } & \text { eicosapentaenoic acid, 20:5 n-3 } \\ \text { FA } & \text { fatty acid } \\ \text { GLA } & \text { gamma-linolenic acid, 18:3 n-6 } \\ \text { LA } & \text { linoleic acid, 18:2 n-6 } \\ \text { MUFA } & \text { monounsaturated fatty acids } \\ \text { NAD } & \text { nicotinamide adenine dinucleotide } \\ \text { NADH } & \text { reduced nicotinamide adenine dinucleotide } \\ \text { NAFLD } & \text { non-alcoholic fatty liver disease } \\ \text { OA } & \text { oleic acid, 18:1 n-9 } \\ \text { PUFA } & \text { polyunsaturated fatty acids } \\ \text { SCD } & \text { stearoyl-CoA desaturase } \\ \text { SDA } & \text { stearidonic acid, 18:4 n-3 } \\ \text { SNP } & \text { trans-vaccenic acid, trans-11 18:1 } \\ \text { VA } & \end{array}$

\section{References}

1. Das, U.N. Biological significance of essential fatty acids. J. Assoc. Physicians India 2006, 54, 309-319. [PubMed]

2. Calder, P.C. Functional Roles of Fatty Acids and Their Effects on Human Health. J. Parenter. Enter. Nutr. 2015, 39, 18S-32S. [CrossRef] [PubMed]

3. Zárate, R.; El Jaber-Vazdekis, N.; Tejera, N.; Pérez, J.A.; Rodríguez, C. Significance of long chain polyunsaturated fatty acids in human health. Clin. Transl. Med. 2017, 6, 25. [CrossRef] [PubMed]

4. Nagy, K.; Tiuca, I.-D. Importance of Fatty Acids in Physiopathology of Human Body. In Fatty Acids; InTech: London, UK, 2017.

5. Massey, K.A.; Nicolaou, A. Lipidomics of polyunsaturated-fatty-acid-derived oxygenated metabolites. Biochem. Soc. Trans. 2011, 39, 1240-1246. [CrossRef]

6. Burdge, G.C. Is essential fatty acid interconversion an important source of PUFA in humans? Br. J. Nutr. 2019, 121, 615-624. [CrossRef]

7. Davidson, J.; Rotondo, D.; Rizzo, M.; Leaver, H. Therapeutic implications of disorders of cell death signalling: Membranes, micro-environment, and eicosanoid and docosanoid metabolism. Br. J. Pharmacol. 2012, 166, 1193-1210. [CrossRef] 
8. de Bus, I.; Witkamp, R.; Zuilhof, H.; Albada, B.; Balvers, M. The role of n-3 PUFA-derived fatty acid derivatives and their oxygenated metabolites in the modulation of inflammation. Prostaglandins Other Lipid Mediat. 2019, 144, 106351. [CrossRef]

9. Sijben, J.W.C.; Calder, P.C. Differential immunomodulation with long-chain n-3 PUFA in health and chronic disease. Proc. Nutr. Soc. 2007, 66, 237-259. [CrossRef]

10. Marventano, S.; Galvano, F.; Buscemi, S.; Mistretta, A. A review of recent evidence in human studies of n-3 and n-6 PUFA intake on cardiovascular disease, cancer, and depressive disorders: Does the ratio really matter? Artic. Int. J. Food Sci. Nutr. 2015. [CrossRef]

11. Kim, W.; Deik, A.; Gonzalez, C.; Gonzalez, M.E.; Fu, F.; Ferrari, M.; Churchhouse, C.L.; Florez, J.C.; Jacobs, S.B.R.; Clish, C.B.; et al. Polyunsaturated Fatty Acid Desaturation Is a Mechanism for Glycolytic NAD + Recycling. Cell Metab. 2019, 29, 856-870.e7. [CrossRef]

12. Huang, J.-Z.; Jiang, X.-Z.; Xia, X.-F.; Yu, A.-Q.; Mao, R.-Y.; Chen, X.-F.; Tian, B.-Y. Cloning and Functional Identification of Delta5 Fatty Acid Desaturase Gene and Its 5'-Upstream Region from Marine Fungus Thraustochytrium sp. FJN-10. Mar. Biotechnol. 2011, 13, 12-21. [CrossRef] [PubMed]

13. Matsuda, T.; Sakaguchi, K.; Hamaguchi, R.; Kobayashi, T.; Abe, E.; Hama, Y.; Hayashi, M.; Honda, D.; Okita, Y.; Sugimoto, S.; et al. Analysis of $\Delta 12$-fatty acid desaturase function revealed that two distinct pathways are active for the synthesis of PUFAs in T. aureum ATCC 34304. J. Lipid Res. 2012, 53, 1210-1222. [CrossRef] [PubMed]

14. Shi, T.; Yu, A.; Li, M.; Ou, X.; Xing, L.; Li, M. Identification of a novel C22- $\Delta 4$-producing docosahexaenoic acid (DHA) specific polyunsaturated fatty acid desaturase gene from Isochrysis galbana and its expression in Saccharomyces cerevisiae. Biotechnol. Lett. 2012, 34, 2265-2274. [CrossRef] [PubMed]

15. Martin-Montalvo, A.; Sun, Y.; Diaz-Ruiz, A.; Ali, A.; Gutierrez, V.; Palacios, H.H.; Curtis, J.; Siendones, E.; Ariza, J.; Abulwerdi, G.A.; et al. Cytochrome b 5 reductase and the control of lipid metabolism and healthspan. NPJ Aging Mech. Dis. 2016, 2. [CrossRef] [PubMed]

16. Zhang, Y.; Wang, H.; Zhang, J.; Hu, Y.; Zhang, L.; Wu, X.; Su, X.; Li, T.; Zou, X.; Liang, B. The cytochrome b5 reductase HPO-19 is required for biosynthesis of polyunsaturated fatty acids in Caenorhabditis elegans. BBA - Mol. Cell Biol. Lipids 2016, 1861, 310-319. [CrossRef] [PubMed]

17. Behrouzian, B.; Buist, P.H. Mechanism of fatty acid desaturation: a bioorganic perspective. Prostaglandins. Leukot. Essent. Fatty Acids 2003, 68, 107-112. [CrossRef]

18. Los, D.A.; Murata, N. Structure and expression of fatty acid desaturases. Biochim. Biophys. Acta - Lipids Lipid Metab. 1998, 1394, 3-15. [CrossRef]

19. Meesapyodsuk, D.; Qiu, X. The Front-end Desaturase: Structure, Function, Evolution and Biotechnological Use. Lipids 2012, 47, 227-237. [CrossRef]

20. Ternes, P.; Franke, S.; Zähringer, U.; Sperling, P.; Heinz, E. Identification and characterization of a sphingolipid delta 4-desaturase family. J. Biol. Chem. 2002, 277, 25512-25518. [CrossRef]

21. Sperling, P.; Ternes, P.; Zank, T.K.; Heinz, E. The evolution of desaturases. Prostaglandins. Leukot. Essent. Fatty Acids 2003, 68, 73-95. [CrossRef]

22. Hucik, B.; Sarr, O.; Nakamura, M.T.; Dyck, D.J.; Mutch, D.M. Reduced delta-6 desaturase activity partially protects against high-fat diet-induced impairment in whole-body glucose tolerance. J. Nutr. Biochem. 2019, 67, 173-181. [CrossRef] [PubMed]

23. Park, W.J.; Kothapalli, K.S.D.; Lawrence, P.; Tyburczy, C.; Brenna, J.T. An alternate pathway to long-chain polyunsaturates: the FADS2 gene product $\triangle 8$-desaturates 20:2n-6 and 20:3n-3. J. Lipid Res. 2009, 50, 1195-1202. [CrossRef] [PubMed]

24. Guillou, H.; Rioux, V.; Catheline, D.; Thibault, J.-N.; Bouriel, M.; Jan, S.; D'Andrea, S.; Legrand, P. Conversion of hexadecanoic acid to hexadecenoic acid by rat $\Delta 6$-desaturase. J. Lipid Res. 2003, 44, 450-454. [CrossRef] [PubMed]

25. Ge, L.; Gordon, J.S.; Hsuan, C.; Stenn, K.; Prouty, S.M. Identification of the $\Delta-6$ Desaturase of Human Sebaceous Glands: Expression and Enzyme Activity. J. Investig. Dermatol. 2003, 120, 707-714. [CrossRef] [PubMed]

26. Harauma, A.; Hatanaka, E.; Yasuda, H.; Nakamura, M.T.; Salem, N.; Moriguchi, T. Effects of arachidonic acid, eicosapentaenoic acid and docosahexaenoic acid on brain development using artificial rearing of delta-6-desaturase knockout mice. Prostaglandins, Leukot. Essent. Fat. Acids 2017, 127, 32-39. [CrossRef] [PubMed] 
27. Sayanova, O.; Haslam, R.; Venegas Caleron, M.; Napier, J.A. Cloning and characterization of unusual fatty acid desaturases from Anemone leveillei: Identification of an acyl-coenzyme A C20 Delta5-desaturase responsible for the synthesis of sciadonic acid. Plant Physiol. 2007, 144, 455-467. [CrossRef] [PubMed]

28. Hong, H.; Datla, N.; Mackenzie, S.L.; Qiu, X. Isolation and characterization of a $\Delta 5$ FA desaturase from Pythium irregulare by heterologous expression in Saccharomyces cerevisiae and oilseed crops. Lipids 2002, 37, 863-868. [CrossRef]

29. Lamers, D.; Visscher, B.; Weusthuis, R.A.; Francke, C.; Wijffels, R.H.; Lokman, C. Overexpression of delta-12 desaturase in the yeast Schwanniomyces occidentalis enhances the production of linoleic acid. Bioresour. Technol. 2019, 289, 121672. [CrossRef]

30. Cripps, C.; Borgeson, C.; Blomquist, G.J.; de Renobales, M. The $\Delta 12$-desaturase from the house cricket, Acheta domesticus (Orthoptera: Gryllidae): Characterization and form of the substrate. Arch. Biochem. Biophys. 1990, 278, 46-51. [CrossRef]

31. Borgeson, C.E.; de Renobales, M.; Blomquist, G.J. Characterization of the $\Delta 12$ desaturase in the American cockroach, Periplaneta americana: The nature of the substrate. Biochim. Biophys. Acta - Lipids Lipid Metab. 1990, 1047, 135-140. [CrossRef]

32. Brandstetter, B.; Ruther, J. An insect with a delta-12 desaturase, the jewel wasp Nasonia vitripennis, benefits from nutritional supply with linoleic acid. Sci. Nat. 2016, 103, 40. [CrossRef] [PubMed]

33. Vessby, B.; Gustafsson, I.-B.; Tengblad, S.; Berglund, L. Indices of fatty acid desaturase activity in healthy human subjects: Effects of different types of dietary fat. Br. J. Nutr. 2013, 110, 871-879. [CrossRef] [PubMed]

34. Joshi, K.; Gadgil, M.; Pandit, A.; Otiv, S.; Kothapalli, K.S.D.; Brenna, J.T. Dietary pattern regulates fatty acid desaturase 1 gene expression in Indian pregnant women to spare overall long chain polyunsaturated fatty acids levels. Mol. Biol. Rep. 2019, 46, 687-693. [CrossRef] [PubMed]

35. Ralston, J.C.; Matravadia, S.; Gaudio, N.; Holloway, G.P.; Mutch, D.M. Polyunsaturated fatty acid regulation of adipocyte FADS1 and FADS2 expression and function. Obesity 2015, 23, 725-728. [CrossRef] [PubMed]

36. Li, S.; Mai, K.; Xu, W.; Yuan, Y.; Zhang, Y.; Ai, Q. Characterization, mRNA expression and regulation of $\delta 6$ fatty acyl desaturase (FADS2) by dietary n-3 long chain polyunsaturated fatty acid (LC-PUFA) levels in grouper larvae (Epinephelus coioides). Aquaculture 2014, 434, 212-219. [CrossRef]

37. Wijendran, V.; Downs, I.; Srigley, C.T.; Kothapalli, K.S.D.; Park, W.J.; Blank, B.S.; Zimmer, J.P.; Butt, C.M.; Salem, N.; Brenna, J.T. Dietary arachidonic acid and docosahexaenoic acid regulate liver fatty acid desaturase (FADS) alternative transcript expression in suckling piglets. Prostaglandins Leukot. Essent. Fat. Acids 2013, 89, 345-350. [CrossRef]

38. Geay, F.; Santigosa I Culi, E.; Corporeau, C.; Boudry, P.; Dreano, Y.; Corcos, L.; Bodin, N.; Vandeputte, M.; Zambonino-Infante, J.L.; Mazurais, D.; et al. Regulation of FADS2 expression and activity in European sea bass (Dicentrarchus labrax, L.) fed a vegetable diet. Comp. Biochem. Physiol. - B Biochem. Mol. Biol. 2010, 156, 237-243. [CrossRef]

39. Brenner, R.R. Hormonal modulation of $\delta 6$ and $\delta 5$ desaturases: Case of diabetes. Prostaglandins Leukot. Essent. Fat. Acids 2003, 68, 151-162. [CrossRef]

40. Childs, C.E.; Romeu-Nadal, M.; Burdge, G.C.; Calder, P.C. The Polyunsaturated Fatty Acid Composition of Hepatic and Plasma Lipids Differ by Both Sex and Dietary Fat Intake in Rats. J. Nutr. 2010, 140, 245-250. [CrossRef]

41. McNamara, R.K.; Able, J.; Jandacek, R.; Rider, T.; Tso, P. Gender differences in rat erythrocyte and brain docosahexaenoic acid composition: Role of ovarian hormones and dietary omega-3 fatty acid composition. Psychoneuroendocrinology 2009, 34, 532-539. [CrossRef]

42. Dong, Y.; Wang, S.; You, C.; Xie, D.; Jiang, Q.; Li, Y. Hepatocyte nuclear factor $4 \alpha(\operatorname{Hnf} 4 \alpha)$ is involved in transcriptional regulation of $\Delta 6 / \Delta 5$ fatty acyl desaturase (fad) gene expression in marine teleost Siganus canaliculatus. Comp. Biochem. Physiol. Part B Biochem. Mol. Biol. 2019, 110353. [CrossRef] [PubMed]

43. Xie, D.; Fu, Z.; Wang, S.; You, C.; Monroig, Ó.; Tocher, D.R.; Li, Y. Characteristics of the fads2 gene promoter in marine teleost Epinephelus coioides and role of Sp1-binding site in determining promoter activit. Sci. Rep. 2018, 8. [CrossRef] [PubMed]

44. Dong, Y.; Zhao, J.; Chen, J.; Wang, S.; Liu, Y.; Zhang, Q.; You, C.; Monroig, Ó.; Tocher, D.R.; Li, Y. Cloning and characterization of $\Delta 6 / \Delta 5$ fatty acyl desaturase (Fad) gene promoter in the marine teleost Siganus canaliculatus. Gene 2018, 647, 174-180. [CrossRef] [PubMed] 
45. Howard, T.D.; Mathias, R.A.; Seeds, M.C.; Herrington, D.M.; Hixson, J.E.; Shimmin, L.C.; Hawkins, G.A.; Sellers, M.; Ainsworth, H.C.; Sergeant, S.; et al. DNA Methylation in an Enhancer Region of the FADS Cluster Is Associated with FADS Activity in Human Liver. PLoS ONE 2014, 9, e97510. [CrossRef] [PubMed]

46. Rahbar, E.; Ainsworth, H.C.; Howard, T.D.; Hawkins, G.A.; Ruczinski, I.; Mathias, R.; Seeds, M.C.; Sergeant, S.; Hixson, J.E.; Herrington, D.M.; et al. Uncovering the DNA methylation landscape in key regulatory regions within the FADS cluster. PLoS ONE 2017, 12, e0180903. [CrossRef] [PubMed]

47. Reddy, A.S.; Nuccio, M.L.; Gross, L.M.; Thomas, T.L. Isolation of a delta 6-desaturase gene from the cyanobacterium Synechocystis sp. strain PCC 6803 by gain-of-function expression in Anabaena sp. strain PCC 7120. Plant Mol. Biol. 1993, 22, 293-300. [CrossRef]

48. Michaelson, L.V.; Lazarus, C.M.; Griffiths, G.; Napier, J.A.; Stobart, A.K. Isolation of a $\Delta^{5}$-Fatty Acid Desaturase Gene from Mortierella alpina. J. Biol. Chem. 1998, 273, 19055-19059. [CrossRef]

49. Wallis, J.G.; Browse, J. The $\Delta 8$-Desaturase ofEuglena gracilis:An Alternate Pathway for Synthesis of 20-Carbon Polyunsaturated Fatty Acids. Arch. Biochem. Biophys. 1999, 365, 307-316. [CrossRef]

50. Diomandé, S.E.; Guinebretière, M.-H.; De Sarrau, B.; Nguyen-the, C.; Broussolle, V.; Brillard, J. Fatty acid profiles and desaturase-encoding genes are different in thermo- and psychrotolerant strains of the Bacillus cereus Group. BMC Res. Notes 2015, 8, 329. [CrossRef]

51. Yoshida, K.; Hashimoto, M.; Hori, R.; Adachi, T.; Okuyama, H.; Orikasa, Y.; Nagamine, T.; Shimizu, S.; Ueno, A.; Morita, N.; et al. Bacterial Long-Chain Polyunsaturated Fatty Acids: Their Biosynthetic Genes, Functions, and Practical Use. Mar. Drugs 2016, 14, 94. [CrossRef]

52. Siliakus, M.F.; van der Oost, J.; Kengen, S.W.M. Adaptations of archaeal and bacterial membranes to variations in temperature, $\mathrm{pH}$ and pressure. Extremophiles 2017, 21, 651-670. [CrossRef] [PubMed]

53. Bale, N.J.; Rijpstra, W.I.C.; Sahonero-Canavesi, D.X.; Oshkin, I.Y.; Belova, S.E.; Dedysh, S.N.; Sinninghe Damsté, J.S. Fatty Acid and Hopanoid Adaption to Cold in the Methanotroph Methylovulum psychrotolerans. Front. Microbiol. 2019, 10, 589. [CrossRef] [PubMed]

54. Okuyama, H.; Orikasa, Y.; Nishida, T.; Watanabe, K.; Morita, N. Bacterial Genes Responsible for the Biosynthesis of Eicosapentaenoic and Docosahexaenoic Acids and Their Heterologous Expression. Appl. Environ. Microbiol. 2007, 51, 730-737. [CrossRef] [PubMed]

55. Martins, D.; Custódio, L.; Barreira, L.; Pereira, H.; Ben-Hamadou, R.; Varela, J.; Abu-Salah, K.; Martins, D.A.; Custódio, L.; Barreira, L.; et al. Alternative Sources of n-3 Long-Chain Polyunsaturated Fatty Acids in Marine Microalgae. Mar. Drugs 2013, 11, 2259-2281. [CrossRef]

56. Marella, E.R.; Holkenbrink, C.; Siewers, V.; Borodina, I. Engineering microbial fatty acid metabolism for biofuels and biochemicals. Curr. Opin. Biotechnol. 2018, 50, 39-46. [CrossRef]

57. Bellou, S.; Triantaphyllidou, I.-E.; Aggeli, D.; Elazzazy, A.M.; Baeshen, M.N.; Aggelis, G. Microbial oils as food additives: Recent approaches for improving microbial oil production and its polyunsaturated fatty acid content. Curr. Opin. Biotechnol. 2016, 37, 24-35. [CrossRef]

58. Winwood, R.J. Micro-organismes producteurs de lipides Recent developments in the commercial production of DHA and EPA rich oils from micro-algae. EDP Sci. 2013, 20.

59. Chauton, M.S.; Reitan, K.I.; Norsker, N.H.; Tveterås, R.; Kleivdal, H.T. A techno-economic analysis of industrial production of marine microalgae as a source of EPA and DHA-rich raw material for aquafeed: Research challenges and possibilities. Aquaculture 2015, 436, 95-103. [CrossRef]

60. Sahin, D.; Tas, E.; Altindag, U.H. Enhancement of docosahexaenoic acid (DHA) production from Schizochytrium sp. S31 using different growth medium conditions. AMB Express 2018, 8, 7. [CrossRef]

61. Peltomaa, E.; Johnson, M.; Taipale, S. Marine Cryptophytes Are Great Sources of EPA and DHA. Mar. Drugs 2017, 16, 3. [CrossRef]

62. Shanklin, J.; Cahoon, E.B. Desaturation and related modifications of fatty acids. Annu. Rev. Plant Physiol. Plant Mol. Biol. 1998, 49, 611-641. [CrossRef] [PubMed]

63. Iba, K. Acclimative response to temperature stress in higher plants: Approaches of Gene Engineering for Temperature Tolerance. Annu. Rev. Plant Biol. 2002, 53, 225-245. [CrossRef] [PubMed]

64. Gibson, S.; Arondel, V.; Iba, K.; Somerville, C. Cloning of a temperature-regulated gene encoding a chloroplast omega-3 desaturase from Arabidopsis thaliana. Plant Physiol. 1994, 106, 1615-1621. [CrossRef] [PubMed]

65. Sun, J.; Chen, M.; Zhu, M.; Jiang, Y.; Meng, J.; Zhao, D.; Tao, J. Cloning, Characterization, and Expression Analysis of Three FAD8 Genes Encoding a Fatty Acid Desaturase from Seeds of Paeonia ostii. Molecules 2018, 23, 929. [CrossRef] [PubMed] 
66. Hazel, J.R.; Eugene Williams, E. The role of alterations in membrane lipid composition in enabling physiological adaptation of organisms to their physical environment. Prog. Lipid Res. 1990, 29, 167-227. [CrossRef]

67. Kodama, H.; Hamada, T.; Horiguchi, G.; Nishimura, M.; Iba, K. Genetic Enhancement of Cold Tolerance by Expression of a Gene for Chloroplast [omega]-3 Fatty Acid Desaturase in Transgenic Tobacco. Plant Physiol. 1994, 105, 601-605. [CrossRef]

68. Murakami, Y.; Tsuyama, M.; Kobayashi, Y.; Kodama, H.; Iba, K. Trienoic fatty acids and plant tolerance of high temperature. Science 2000, 287, 476-479. [CrossRef]

69. Zhang, J.-T.; Zhu, J.-Q.; Zhu, Q.; Liu, H.; Gao, X.-S.; Zhang, H.-X. Fatty acid desaturase-6 (Fad6) is required for salt tolerance in Arabidopsis thaliana. Biochem. Biophys. Res. Commun. 2009, 390, 469-474. [CrossRef]

70. Zhang, J.; Liu, H.; Sun, J.; Li, B.; Zhu, Q.; Chen, S.; Zhang, H. Arabidopsis Fatty Acid Desaturase FAD2 Is Required for Salt Tolerance during Seed Germination and Early Seedling Growth. PLoS ONE 2012, 7, e30355. [CrossRef]

71. Hernández, M.L.; Sicardo, M.D.; Martínez-Rivas, J.M. Differential Contribution of Endoplasmic Reticulum and Chloroplast $\omega-3$ Fatty Acid Desaturase Genes to the Linolenic Acid Content of Olive (Olea europaea) Fruit. Plant Cell Physiol. 2016, 57, 138-151. [CrossRef]

72. Lakra, N.; Mahmood, S.; Marwal, A.; Sudheep, N.M.; Anwar, K. Bioengineered Plants Can Be an Alternative Source of Omega-3 Fatty Acids for Human Health. In Plant and Human Health, Volume 2; Springer International Publishing: Cham, Switzerland, 2019; pp. 361-382.

73. Qiu, X.; Hong, H.; Datla, N.; MacKenzie, S.L.; Taylor, D.C.; Thomas, T.L. Expression of borage $\Delta 6$ desaturase in Saccharomyces cerevisiae and oilseed crops. Can. J. Bot. 2002, 80, 42-49. [CrossRef]

74. Sayanova, O.; Smith, M.A.; Lapinskas, P.; Stobart, A.K.; Dobson, G.; Christie, W.W.; Shewry, P.R.; Napier, J.A. Expression of a borage desaturase cDNA containing an N-terminal cytochrome b5 domain results in the accumulation of high levels of delta6-desaturated fatty acids in transgenic tobacco. Proc. Natl. Acad. Sci. USA 1997, 94, 4211-4216. [CrossRef] [PubMed]

75. Ruiz-López, N.; Haslam, R.P.; Venegas-Calerón, M.; Larson, T.R.; Graham, I.A.; Napier, J.A.; Sayanova, O. The synthesis and accumulation of stearidonic acid in transgenic plants: A novel source of 'heart-healthy' omega-3 fatty acids. Plant Biotechnol. J. 2009, 7, 704-716. [CrossRef] [PubMed]

76. Okuzaki, A.; Ogawa, T.; Koizuka, C.; Kaneko, K.; Inaba, M.; Imamura, J.; Koizuka, N. CRISPR/Cas9-mediated genome editing of the fatty acid desaturase 2 gene in Brassica napus. Plant Physiol. Biochem. 2018, 131, 63-69. [CrossRef]

77. Shrestha, P.; Zhou, X.-R.; Vibhakaran Pillai, S.; Petrie, J.; de Feyter, R.; Singh, S. Comparison of the Substrate Preferences of $\omega 3$ Fatty Acid Desaturases for Long Chain Polyunsaturated Fatty Acids. Int. J. Mol. Sci. 2019, 20, 3058. [CrossRef]

78. Cheng, B.; Wu, G.; Vrinten, P.; Falk, K.; Bauer, J.; Qiu, X. Towards the production of high levels of eicosapentaenoic acid in transgenic plants: The effects of different host species, genes and promoters. Transgenic Res. 2010, 19, 221-229. [CrossRef]

79. Damude, H.G.; Kinney, A.J. Engineering Oilseed Plants for a Sustainable, Land-Based Source of Long Chain Polyunsaturated Fatty Acids. Lipids 2007, 42, 179-185. [CrossRef]

80. Ruiz-Lopez, N.; Haslam, R.P.; Usher, S.L.; Napier, J.A.; Sayanova, O. Reconstitution of EPA and DHA biosynthesis in Arabidopsis: Iterative metabolic engineering for the synthesis of $n-3$ LC-PUFAs in transgenic plants. Metab. Eng. 2013, 17, 30-41. [CrossRef]

81. Usher, S.; Haslam, R.P.; Ruiz-Lopez, N.; Sayanova, O.; Napier, J.A. Field trial evaluation of the accumulation of omega-3 long chain polyunsaturated fatty acids in transgenic Camelina sativa: Making fish oil substitutes in plants. Metab. Eng. Commun. 2015, 2, 93-98. [CrossRef]

82. Marwal, A.; Anwar, K. Bioengineered Plants Can Be an Alternative Source of Omega-3 Fatty Acids for Human Health: Phytochemistry and Molecular Aspects. In Plant and Human Health; Springer: Cham, Switzerland, 2019.

83. Coppens, P.; da Silva, M.F.; Pettman, S. European regulations on nutraceuticals, dietary supplements and functional foods: A framework based on safety. Toxicology 2006, 221, 59-74. [CrossRef]

84. Starr, R.R. Too Little, Too Late: Ineffective Regulation of Dietary Supplements in the United States. Am. J. Public Health 2015, 105, 478. [CrossRef] [PubMed]

85. Resnik, D.B. Proportionality in Public Health Regulation: The Case of Dietary Supplements. Food Ethics 2017. [CrossRef] [PubMed] 
86. Salvador, A.M.; García-Maldonado, E.; Gallego-Narbón, A.; Zapatera, B.; Vaquero, M.P. Fatty Acid Profile and Cardiometabolic Markers in Relation with Diet Type and Omega-3 Supplementation in Spanish Vegetarians. Nutrients 2019, 11, 1659. [CrossRef] [PubMed]

87. Yu, X.; Huang, T.; Weng, X.; Shou, T.; Wang, Q.; Zhou, X.; Hu, Q.; Li, D. Plasma n-3 and n-6 fatty acids and inflammatory markers in Chinese vegetarians. Lipids Health Dis. 2014, 13, 151. [CrossRef] [PubMed]

88. Sanders, T.A.B. Polyunsaturated Fatty Acid Status in Vegetarians. In Vegetarian and Plant-Based Diets in Health and Disease Prevention; Elsevier Inc.: Amsterdam, the Netherlands, 2017; pp. 667-681. ISBN 9780128039694.

89. Tanaka, T.; Shen, J.; Abecasis, G.R.; Kisialiou, A.; Ordovas, J.M.; Guralnik, J.M.; Singleton, A.; Bandinelli, S.; Cherubini, A.; Arnett, D.; et al. Genome-wide association study of plasma polyunsaturated fatty acids in the InCHIANTI Study. PLoS Genet. 2009, 5, e1000338. [CrossRef] [PubMed]

90. Merino, D.M.; Johnston, H.; Clarke, S.; Roke, K.; Nielsen, D.; Badawi, A.; El-Sohemy, A.; Ma, D.W.L.; Mutch, D.M. Polymorphisms in FADS1 and FADS2 alter desaturase activity in young Caucasian and Asian adults. Mol. Genet. Metab. 2011, 103, 171-178. [CrossRef]

91. de Toro-Martín, J.; Guénard, F.; Rudkowska, I.; Lemieux, S.; Couture, P.; Vohl, M.-C.C. A common variant in ARHGEF10 alters delta-6 desaturase activity and influence susceptibility to hypertriglyceridemia. J. Clin. Lipidol. 2018, 12, 311-320.e3. [CrossRef]

92. Xie, L.; Innis, S.M. Association of Fatty Acid Desaturase Gene Polymorphisms with Blood Lipid Essential Fatty Acids and Perinatal Depression among Canadian Women: A Pilot Study. J. Nutrigenet. Nutrigenomics 2009, 2, 243-250. [CrossRef]

93. Zhang, J.Y.; Kothapalli, K.S.D.; Brenna, J.T. Desaturase and elongase-limiting endogenous long-chain polyunsaturated fatty acid biosynthesis. Curr. Opin. Clin. Nutr. Metab. Care 2016, 19, 103-110. [CrossRef]

94. Dumont, J.; Huybrechts, I.; Spinneker, A.; Gottrand, F.; Grammatikaki, E.; Bevilacqua, N.; Vyncke, K.; Widhalm, K.; Kafatos, A.; Molnar, D.; et al. FADS1 Genetic Variability Interacts with Dietary $\alpha$-Linolenic Acid Intake to Affect Serum Non-HDL-Cholesterol Concentrations in European Adolescents. J. Nutr. 2011, 141, 1247-1253. [CrossRef]

95. Meldrum, S.J.; Li, Y.; Zhang, G.; Heaton, A.E.M.; D’vaz, N.; Manz, J.; Reischl, E.; Berthold; Koletzko, V.; Prescott, S.L.; et al. Can polymorphisms in the fatty acid desaturase (FADS) gene cluster alter the effects of fish oil supplementation on plasma and erythrocyte fatty acid profiles? An exploratory study. Eur. J. Nutr. 2018, 57, 2583-2594. [CrossRef]

96. Czajkowska, M.; Brzęk, P.; Dobrzyń, P. A novel polymorphism in the fatty acid desaturase 2 gene (Fads2): A possible role in the basal metabolic rate. PLoS ONE 2019, 14, e213138. [CrossRef]

97. Garcia, C.; Guillocheau, E.; Richard, L.; Drouin, G.; Catheline, D.; Legrand, P.; Rioux, V. Conversion of dietary trans-vaccenic acid to trans11,cis13-conjugated linoleic acid in the rat lactating mammary gland by Fatty Acid Desaturase 3-catalyzed methyl-end $\Delta 13$-desaturation. Biochem. Biophys. Res. Commun. 2018, 505, 385-391. [CrossRef] [PubMed]

98. Garcia, C.; Duby, C.; Catheline, D.; Toral, P.G.; Bernard, L.; Legrand, P.; Rioux, V. Synthesis of the suspected trans-11,cis-13 conjugated linoleic acid isomer in ruminant mammary tissue by FADS3-catalyzed $\Delta$ 13-desaturation of vaccenic acid. J. Dairy Sci. 2017, 100, 783-796. [CrossRef] [PubMed]

99. de la Garza Puentes, A.; Montes Goyanes, R.; Chisaguano Tonato, A.M.; Torres-Espínola, F.J.; Arias García, M.; de Almeida, L.; Bonilla Aguirre, M.; Guerendiain, M.; Castellote Bargalló, A.I.; Segura Moreno, M.; et al. Association of maternal weight with FADS and ELOVL genetic variants and fatty acid levels- The PREOBE follow-up. PLoS ONE 2017, 12, e0179135. [CrossRef] [PubMed]

100. Wang, L.; Athinarayanan, S.; Jiang, G.; Chalasani, N.; Zhang, M.; Liu, W. Fatty Acid Desaturase 1 Gene Polymorphisms Control Human Hepatic Lipid Composition. Hepatology 2014.

101. Kwak, J.H.; Paik, J.K.; Kim, O.Y.; Jang, Y.; Lee, S.H.; Ordovas, J.M.; Lee, J.H. FADS gene polymorphisms in Koreans: Association with $\omega 6$ polyunsaturated fatty acids in serum phospholipids, lipid peroxides, and coronary artery disease. Atherosclerosis 2011, 214, 94-100. [CrossRef]

102. Li, S.W.; Lin, K.; Ma, P.; Zhang, Z.L.; Zhou, Y.D.; Lu, S.Y.; Zhou, X.; Liu, S.M. FADS Gene Polymorphisms Confer the Risk of Coronary Artery Disease in a Chinese Han Population through the Altered Desaturase Activities: Based on High-Resolution Melting Analysis. PLoS ONE 2013, 8. [CrossRef] [PubMed]

103. Li, S.-W.; Wang, J.; Yang, Y.; Liu, Z.-J.; Cheng, L.; Liu, H.-Y.; Ma, P.; Luo, W.; Liu, S.-M. Polymorphisms in FADS1 and FADS2 alter plasma fatty acids and desaturase levels in type 2 diabetic patients with coronary artery disease. J. Transl. Med. 2016, 14, 79. [CrossRef] 
104. Liu, F.; Li, Z.; Lv, X.; Ma, J. Dietary n-3 Polyunsaturated Fatty Acid Intakes Modify the Effect of Genetic Variation in Fatty Acid Desaturase 1 on Coronary Artery Disease. PLoS ONE 2015, 10, e0121255. [CrossRef]

105. Kanai, M.; Akiyama, M.; Takahashi, A.; Matoba, N.; Momozawa, Y.; Ikeda, M.; Iwata, N.; Ikegawa, S.; Hirata, M.; Matsuda, K.; et al. Genetic analysis of quantitative traits in the Japanese population links cell types to complex human diseases. Nat. Genet. 2018, 50, 390-400. [CrossRef] [PubMed]

106. Stahl, E.A.; Breen, G.; Forstner, A.J.; McQuillin, A.; Ripke, S.; Trubetskoy, V.; Mattheisen, M.; Wang, Y.; Coleman, J.R.I.; Gaspar, H.A.; et al. Genome-wide association study identifies 30 loci associated with bipolar disorder. Nat. Genet. 2019, 51, 793-803. [CrossRef] [PubMed]

107. Ikeda, M.; Takahashi, A.; Kamatani, Y.; Okahisa, Y.; Kunugi, H.; Mori, N.; Sasaki, T.; Ohmori, T.; Okamoto, Y.; Kawasaki, H.; et al. A genome-wide association study identifies two novel susceptibility loci and trans population polygenicity associated with bipolar disorder. Mol. Psychiatry 2018, 23, 639-647. [CrossRef] [PubMed]

108. Mychaleckyj, J.C.; Nayak, U.; Colgate, E.R.; Zhang, D.; Carstensen, T.; Ahmed, S.; ahmed, T.; Mentzer, A.J.; Alam, M.; Kirkpatrick, B.D.; et al. Multiplex genomewide association analysis of breast milk fatty acid composition extends the phenotypic association and potential selection of FADS1 variants to arachidonic acid, a critical infant micronutrient. J. Med. Genet. 2018, 55, 459-468.

109. Wei, Q.; Yu, D.; Liu, M.; Wang, M.; Zhao, M.; Liu, M.; Jia, W.; Ma, H.; Fang, J.; Xu, W.; et al. Genome-wide association study identifies three susceptibility loci for laryngeal squamous cell carcinoma in the Chinese population. Nat. Genet. 2014, 46, 1110-1114. [CrossRef]

110. Giri, A.; Hellwege, J.N.; Keaton, J.M.; Park, J.; Qiu, C.; Warren, H.R.; Torstenson, E.S.; Kovesdy, C.P.; Sun, Y.V.; Wilson, O.D.; et al. Trans-ethnic association study of blood pressure determinants in over 750,000 individuals. Nat. Genet. 2019, 51, 51-62. [CrossRef]

111. van Setten, J.; Verweij, N.; Mbarek, H.; Niemeijer, M.N.; Trompet, S.; Arking, D.E.; Brody, J.A.; Gandin, I.; Grarup, N.; Hall, L.M.; et al. Genome-wide association meta-analysis of 30,000 samples identifies seven novel loci for quantitative ECG traits. Eur. J. Hum. Genet. 2019, 27, 952-962. [CrossRef]

112. Eijgelsheim, M.; Newton-Cheh, C.; Sotoodehnia, N.; de bakker, P.I.W.; Müller, M.; Morrison, A.C.; Smith, A.V.; Isaacs, A.; Sanna, S.; Dörr, M.; et al. Genome-wide association analysis identifies multiple loci related to resting heart rate. Hum. Mol. Genet. 2010, 19, 3885-3894. [CrossRef]

113. Den Hoed, M.; Eijgelsheim, M.; Esko, T.; Brundel, B.J.J.M.; Peal, D.S.; Evans, D.M.; Nolte, I.M.; Segrè, A.V.; Holm, H.; Handsaker, R.E.; et al. Identification of heart rate-associated loci and their effects on cardiac conduction and rhythm disorders. Nat. Genet. 2013, 45, 621-631. [CrossRef]

114. Surakka, I.; Horikoshi, M.; Mägi, R.; Sarin, A.P.; Mahajan, A.; Lagou, V.; Marullo, L.; Ferreira, T.; Miraglio, B.; Timonen, S.; et al. The impact of low-frequency and rare variants on lipid levels. Nat. Genet. 2015, 47, 589-597. [CrossRef]

115. Teslovich, T.M.; Musunuru, K.; Smith, A.V.; Edmondson, A.C.; Stylianou, I.M.; Koseki, M.; Pirruccello, J.P.; Ripatti, S.; Chasman, D.I.; Willer, C.J.; et al. Biological, clinical and population relevance of 95 loci for blood lipids. Nature 2010, 466, 707-713. [CrossRef] [PubMed]

116. Willer, C.J.; Schmidt, E.M.; Sengupta, S.; Peloso, G.M.; Gustafsson, S.; Kanoni, S.; Ganna, A.; Chen, J.; Buchkovich, M.L.; Mora, S.; et al. Discovery and refinement of loci associated with lipid levels. Nat. Genet. 2013, 45, 1274-1285. [PubMed]

117. Kathiresan, S.; Willer, C.J.; Peloso, G.M.; Demissie, S.; Musunuru, K.; Schadt, E.E.; Kaplan, L.; Bennett, D.; Li, Y.; Tanaka, T.; et al. Common variants at 30 loci contribute to polygenic dyslipidemia. Nat. Genet. 2009, 41, 56-65. [CrossRef] [PubMed]

118. Waterworth, D.M.; Ricketts, S.L.; Song, K.; Chen, L.; Zhao, J.H.; Ripatti, S.; Aulchenko, Y.S.; Zhang, W.; Yuan, X.; Lim, N.; et al. Genetic variants influencing circulating lipid levels and risk of coronary artery disease. Arterioscler. Thromb. Vasc. Biol. 2010, 30, 2264-2276. [CrossRef]

119. Spracklen, C.N.; Chen, P.; Kim, Y.J.; Wang, X.; Cai, H.; Li, S.; Long, J.; Wu, Y.; Wang, Y.X.; Takeuchi, F.; et al. Association analyses of East Asian individuals and trans-ancestry analyses with European individuals reveal new loci associated with cholesterol and triglyceride levels. Hum. Mol. Genet. 2017, 26, 1770-1784. [CrossRef]

120. Bentley, A.R.; Sung, Y.J.; Brown, M.R.; Winkler, T.W.; Kraja, A.T.; Ntalla, I.; Schwander, K.; Chasman, D.I.; Lim, E.; Deng, X.; et al. Multi-ancestry genome-wide gene-smoking interaction study of 387,272 individuals identifies new loci associated with serum lipids. Nat. Genet. 2019, 51, 636-648. [CrossRef] 
121. De Vries, P.S.; Brown, M.R.; Bentley, A.R.; Sung, Y.J.; Winkler, T.W.; Ntalla, I.; Schwander, K.; Kraja, A.T.; Guo, X.; Franceschini, N.; et al. Multiancestry Genome-Wide Association Study of Lipid Levels Incorporating Gene-Alcohol Interactions. Am. J. Epidemiol. 2019, 188, 1033-1054. [CrossRef]

122. Kulminski, A.M.; Huang, J.; Loika, Y.; Arbeev, K.G.; Bagley, O.; Yashkin, A.; Duan, M.; Culminskaya, I. Strong impact of natural-selection-free heterogeneity in genetics of age-related phenotypes. Aging (Albany. NY). 2018, 10, 492-514. [CrossRef]

123. Wojcik, G.L.; Graff, M.; Nishimura, K.K.; Tao, R.; Haessler, J.; Gignoux, C.R.; Highland, H.M.; Patel, Y.M.; Sorokin, E.P.; Avery, C.L.; et al. Genetic analyses of diverse populations improves discovery for complex traits. Nature 2019, 570,514-518. [CrossRef]

124. Hoffmann, T.J.; Theusch, E.; Haldar, T.; Ranatunga, D.K.; Jorgenson, E.; Medina, M.W.; Kvale, M.N.; Kwok, P.Y.; Schaefer, C.; Krauss, R.M.; et al. A large electronic-health-record-based genome-wide study of serum lipids. Nat. Genet. 2018, 50, 401-413. [CrossRef]

125. Sabatti, C.; Service, S.K.; Hartikainen, A.L.; Pouta, A.; Ripatti, S.; Brodsky, J.; Jones, C.G.; Zaitlen, N.A.; Varilo, T.; Kaakinen, M.; et al. Genome-wide association analysis of metabolic traits in a birth cohort from a founder population. Nat. Genet. 2009, 41, 35-46. [CrossRef] [PubMed]

126. Klarin, D.; Damrauer, S.M.; Cho, K.; Sun, Y.V.; Teslovich, T.M.; Honerlaw, J.; Gagnon, D.R.; DuVall, S.L.; Li, J.; Peloso, G.M.; et al. Genetics of blood lipids among 300,000 multi-ethnic participants of the Million Veteran Program. Nat. Genet. 2018, 50, 1514-1523. [CrossRef] [PubMed]

127. Kilpeläinen, T.O.; Bentley, A.R.; Noordam, R.; Sung, Y.J.; Schwander, K.; Winkler, T.W.; Jakupović, H.; Chasman, D.I.; Manning, A.; Ntalla, I.; et al. Multi-ancestry study of blood lipid levels identifies four loci interacting with physical activity. Nat. Commun. 2019, 10. [CrossRef] [PubMed]

128. Wessel, J.; Chu, A.Y.; Willems, S.M.; Wang, S.; Yaghootkar, H.; Brody, J.A.; Dauriz, M.; Hivert, M.F.; Raghavan, S.; Lipovich, L.; et al. Low-frequency and rare exome chip variants associate with fasting glucose and type 2 diabetes susceptibility. Nat. Commun. 2015, 6. [CrossRef] [PubMed]

129. Manning, A.K.; Hivert, M.F.; Scott, R.A.; Grimsby, J.L.; Bouatia-Naji, N.; Chen, H.; Rybin, D.; Liu, C.T.; Bielak, L.F.; Prokopenko, I.; et al. A genome-wide approach accounting for body mass index identifies genetic variants influencing fasting glycemic traits and insulin resistance. Nat. Genet. 2012, 44, 659-669. [CrossRef]

130. Dupuis, J.; Langenberg, C.; Prokopenko, I.; Saxena, R.; Soranzo, N.; Jackson, A.U.; Wheeler, E.; Glazer, N.L.; Bouatia-Naji, N.; Gloyn, A.L.; et al. New genetic loci implicated in fasting glucose homeostasis and their impact on type 2 diabetes risk. Nat. Genet. 2010, 42, 105-116. [CrossRef]

131. Dorajoo, R.; Sun, Y.; Han, Y.; Ke, T.; Burger, A.; Chang, X.; Low, H.Q.; Guan, W.; Lemaitre, R.N.; Khor, C.C.; et al. A genome-wide association study of n-3 and n-6 plasma fatty acids in a Singaporean Chinese population. Genes Nutr. 2015, 10,1-11. [CrossRef]

132. Marklund, M.; Morris, A.P.; Mahajan, A.; Ingelsson, E.; Lindgren, C.M.; Lind, L.; Risérus, U. Genome-wide association studies of estimated fatty acid desaturase activity in serum and adipose tissue in elderly individuals: Associations with insulin sensitivity. Nutrients 2018, 10, 1791. [CrossRef]

133. Kichaev, G.; Bhatia, G.; Loh, P.R.; Gazal, S.; Burch, K.; Freund, M.K.; Schoech, A.; Pasaniuc, B.; Price, A.L. Leveraging Polygenic Functional Enrichment to Improve GWAS Power. Am. J. Hum. Genet. 2019, 104, 65-75. [CrossRef]

134. Astle, W.J.; Elding, H.; Jiang, T.; Allen, D.; Ruklisa, D.; Mann, A.L.; Mead, D.; Bouman, H.; Riveros-Mckay, F.; Kostadima, M.A.; et al. The Allelic Landscape of Human Blood Cell Trait Variation and Links to Common Complex Disease. Cell 2016, 167, 1415-1429.e19. [CrossRef]

135. Hong, K.W.; Jin, H.S.; Song, D.; Kwak, H.K.; Kim, S.S.; Kim, Y. Genome-wide association study of serum albumin:globulin ratio in Korean populations. J. Hum. Genet. 2013, 58, 174-177. [CrossRef] [PubMed]

136. Jonsson, S.; Sveinbjornsson, G.; De Lapuente Portilla, A.L.; Swaminathan, B.; Plomp, R.; Dekkers, G.; Ajore, R.; Ali, M.; Bentlage, A.E.H.; Elmér, E.; et al. Identification of sequence variants influencing immunoglobulin levels. Nat. Genet. 2017, 49, 1182-1191. [CrossRef] [PubMed]

137. Pilling, L.C.; Atkins, J.L.; Duff, M.O.; Beaumont, R.N.; Jones, S.E.; Tyrrell, J.; Kuo, C.L.; Ruth, K.S.; Tuke, M.A.; Yaghootkar, H.; et al. Red blood cell distribution width: Genetic evidence for aging pathways in 116,666 volunteers. PLoS ONE 2017, 12. [CrossRef] [PubMed]

138. He, M.; Xu, M.; Zhang, B.; Liang, J.; Chen, P.; Lee, J.Y.; Johnson, T.A.; Li, H.; Yang, X.; Dai, J.; et al. Meta-analysis of genome-wide association studies of adult height in East Asians identifies 17 novel loci. Hum. Mol. Genet. 2015, 24, 1791-1800. [CrossRef] [PubMed] 
139. Lemaitre, R.N.; Tanaka, T.; Tang, W.; Manichaikul, A.; Foy, M.; Kabagambe, E.K.; Nettleton, J.A.; King, I.B.; Weng, L.C.; Bhattacharya, S.; et al. Genetic loci associated with plasma phospholipid N-3 fatty acids: A Meta-Analysis of Genome-Wide association studies from the charge consortium. PLoS Genet. 2011, 7. [CrossRef] [PubMed]

140. Guan, W.; Steffen, B.T.; Lemaitre, R.N.; Wu, J.H.Y.; Tanaka, T.; Manichaikul, A.; Foy, M.; Rich, S.S.; Wang, L.; Nettleton, J.A.; et al. Genome-Wide association study of plasma n6 polyunsaturated fatty acids within the cohorts for heart and aging research in genomic epidemiology consortium. Circ. Cardiovasc. Genet. 2014, 7, 321-331. [CrossRef]

141. Pividori, M.; Schoettler, N.; Nicolae, D.L.; Ober, C.; Im, H.K. Shared and distinct genetic risk factors for childhood-onset and adult-onset asthma: Genome-wide and transcriptome-wide studies. Lancet Respir. Med. 2019, 7, 509-522. [CrossRef]

142. Yap, C.X.; Sidorenko, J.; Wu, Y.; Kemper, K.E.; Yang, J.; Wray, N.R.; Robinson, M.R.; Visscher, P.M. Dissection of genetic variation and evidence for pleiotropy in male pattern baldness. Nat. Commun. 2018, 9. [CrossRef]

143. Hagenaars, S.P.; Hill, W.D.; Harris, S.E.; Ritchie, S.J.; Davies, G.; Liewald, D.C.; Gale, C.R.; Porteous, D.J.; Deary, I.J.; Marioni, R.E. Genetic prediction of male pattern baldness. PLOS Genet. 2017, 13, e1006594. [CrossRef]

144. Schmit, S.L.; Edlund, C.K.; Schumacher, F.R.; Gong, J.; Harrison, T.A.; Huyghe, J.R.; Qu, C.; Melas, M.; Van Den Berg, D.J.; Wang, H.; et al. Novel common genetic susceptibility loci for colorectal cancer. J. Natl. Cancer Inst. 2019, 111, 146-157. [CrossRef]

145. Tanikawa, C.; Kamatani, Y.; Takahashi, A.; Momozawa, Y.; Leveque, K.; Nagayama, S.; Mimori, K.; Mori, M.; Ishii, H.; Inazawa, J.; et al. GWAS identifies two novel colorectal cancer loci at 16q24.1 and 20q13.12. Carcinogenesis 2018, 39, 652-660. [CrossRef] [PubMed]

146. Law, P.J.; Timofeeva, M.; Fernandez-Rozadilla, C.; Broderick, P.; Studd, J.; Fernandez-Tajes, J.; Farrington, S.; Svinti, V.; Palles, C.; Orlando, G.; et al. Association analyses identify 31 new risk loci for colorectal cancer susceptibility. Nat. Commun. 2019, 10. [CrossRef] [PubMed]

147. McKay, J.D.; Hung, R.J.; Han, Y.; Zong, X.; Carreras-Torres, R.; Christiani, D.C.; Caporaso, N.E.; Johansson, M.; Xiao, X.; Li, Y.; et al. Large-scale association analysis identifies new lung cancer susceptibility loci and heterogeneity in genetic susceptibility across histological subtypes. Nat. Genet. 2017, 49, 1126-1132. [CrossRef] [PubMed]

148. Verweij, N.; Leach, I.M.; Van Den Boogaard, M.; Van Veldhuisen, D.J.; Christoffels, V.M.; Hillege, H.L.; Van Gilst, W.H.; Barnett, P.; De Boer, R.A.; Van Der Harst, P. Genetic Determinants of P Wave Duration and PR Segment. Circ. Cardiovasc. Genet. 2014, 7, 475-481. [CrossRef]

149. van der Harst, P.; van Setten, J.; Verweij, N.; Vogler, G.; Franke, L.; Maurano, M.T.; Wang, X.; Mateo Leach, I.; Eijgelsheim, M.; Sotoodehnia, N.; et al. 52 Genetic Loci Influencing Myocardial Mass. J. Am. Coll. Cardiol. 2016, 68, 1435-1448. [CrossRef]

150. Arking, D.E.; Pulit, S.L.; Crotti, L.; Van Der Harst, P.; Munroe, P.B.; Koopmann, T.T.; Sotoodehnia, N.; Rossin, E.J.; Morley, M.; Wang, X.; et al. Genetic association study of QT interval highlights role for calcium signaling pathways in myocardial repolarization. Nat. Genet. 2014, 46, 826-836. [CrossRef]

151. Andaleon, A.; Mogil, L.S.; Wheeler, H.E. Genetically regulated gene expression underlies lipid traits in Hispanic cohorts. PLoS ONE 2019, 14, e0220827. [CrossRef]

152. Aulchenko, Y.S.; Ripatti, S.; Lindqvist, I.; Boomsma, D.; Heid, I.M.; Pramstaller, P.P.; Penninx, B.W.J.H.; Janssens, A.C.J.W.; Wilson, J.F.; Spector, T.; et al. Loci influencing lipid levels and coronary heart disease risk in 16 European population cohorts. Nat. Genet. 2009, 41, 47-55.

153. Han, Y.; Pei, Y.; Liu, Y.; Zhang, L.; Wu, S.; Tian, Q.; Chen, X.; Shen, H.; Zhu, X.; Papasian, C.J.; et al. Bivariate genome-wide association study suggests fatty acid desaturase genes and cadherin DCHS2 for variation of both compressive strength index and appendicular lean mass in males. Bone 2012, 51, 1000-1007. [CrossRef]

154. Hu, Y.; Tanaka, T.; Zhu, J.; Guan, W.; Wu, J.H.Y.; Psaty, B.M.; McKnight, B.; King, I.B.; Sun, Q.; Richard, M.; et al. Discovery and fine-mapping of loci associated with MUFAs through trans-ethnic meta-analysis in Chinese and European populations. J. Lipid Res. 2017, 58, 974-981. [CrossRef]

155. Chen, P.; Takeuchi, F.; Lee, J.Y.; Li, H.; Wu, J.Y.; Liang, J.; Long, J.; Tabara, Y.; Goodarzi, M.O.; Pereira, M.A.; et al. Multiple nonglycemic genomic loci are newly associated with blood level of glycated hemoglobin in East Asians. Diabetes 2014, 63, 2551-2562. [CrossRef] 
156. Wheeler, E.; Leong, A.; Liu, C.T.; Hivert, M.F.; Strawbridge, R.J.; Podmore, C.; Li, M.; Yao, J.; Sim, X.; Hong, J.; et al. Impact of common genetic determinants of Hemoglobin A1c on type 2 diabetes risk and diagnosis in ancestrally diverse populations: A transethnic genome-wide meta-analysis. PLoS Med. 2017, 14. [CrossRef] [PubMed]

157. Benyamin, B.; Esko, T.; Ried, J.S.; Radhakrishnan, A.; Vermeulen, S.H.; Traglia, M.; Gögele, M.; Anderson, D.; Broer, L.; Podmore, C.; et al. Novel loci affecting iron homeostasis and their effects in individuals at risk for hemochromatosis. Nat. Commun. 2014, 5. [CrossRef] [PubMed]

158. Kemp, J.P.; Morris, J.A.; Medina-Gomez, C.; Forgetta, V.; Warrington, N.M.; Youlten, S.E.; Zheng, J.; Gregson, C.L.; Grundberg, E.; Trajanoska, K.; et al. Identification of 153 new loci associated with heel bone mineral density and functional involvement of GPC6 in osteoporosis. Nat. Genet. 2017, 49, 1468-1475. [CrossRef] [PubMed]

159. Kim, S.K. Identification of 613 new loci associated with heel bone mineral density and a polygenic risk score for bone mineral density, osteoporosis and fracture. PLoS ONE 2018, 13, e0200785. [CrossRef] [PubMed]

160. Liu, J.Z.; Van Sommeren, S.; Huang, H.; Ng, S.C.; Alberts, R.; Takahashi, A.; Ripke, S.; Lee, J.C.; Jostins, L.; Shah, T.; et al. Association analyses identify 38 susceptibility loci for inflammatory bowel disease and highlight shared genetic risk across populations. Nat. Genet. 2015, 47, 979-986. [CrossRef] [PubMed]

161. Jostins, L.; Ripke, S.; Weersma, R.K.; Duerr, R.H.; McGovern, D.P.; Hui, K.Y.; Lee, J.C.; Philip Schumm, L.; Sharma, Y.; Anderson, C.A.; et al. Host-microbe interactions have shaped the genetic architecture of inflammatory bowel disease. Nature 2012, 491, 119-124. [CrossRef] [PubMed]

162. Okada, Y.; Wu, D.; Trynka, G.; Raj, T.; Terao, C.; Ikari, K.; Kochi, Y.; Ohmura, K.; Suzuki, A.; Yoshida, S.; et al. Genetics of rheumatoid arthritis contributes to biology and drug discovery. Nature 2014, 506, 376-381. [CrossRef]

163. Laufer, V.A.; Tiwari, H.K.; Reynolds, R.J.; Danila, M.I.; Wang, J.; Edberg, J.C.; Kimberly, R.P.; Kottyan, L.C.; Harley, J.B.; Mikuls, T.R.; et al. Genetic influences on susceptibility to rheumatoid arthritis in African-Americans. Hum. Mol. Genet. 2019, 28, 858-874. [CrossRef]

164. Dashti, H.S.; Jones, S.E.; Wood, A.R.; Lane, J.M.; van Hees, V.T.; Wang, H.; Rhodes, J.A.; Song, Y.; Patel, K.; Anderson, S.G.; et al. Genome-wide association study identifies genetic loci for self-reported habitual sleep duration supported by accelerometer-derived estimates. Nat. Commun. 2019, 10. [CrossRef]

165. Hicks, A.A.; Pramstaller, P.P.; Johansson, Å.; Vitart, V.; Rudan, I.; Ugocsai, P.; Aulchenko, Y.; Franklin, C.S.; Liebisch, G.; Erdmann, J.; et al. Genetic determinants of circulating sphingolipid concentrations in European populations. PLoS Genet. 2009, 5. [CrossRef] [PubMed]

166. Mozaffarian, D.; Kabagambe, E.K.; Johnson, C.O.; Lemaitre, R.N.; Manichaikul, A.; Sun, Q.; Foy, M.; Wang, L.; Wiener, H.; Irvin, M.R.; et al. Genetic loci associated with circulating phospholipid trans fatty acids: A meta-analysis of genome-wide association studies from the CHARGE consortium. Am. J. Clin. Nutr. 2015, 101, 398-406. [CrossRef] [PubMed]

167. Izadi, F. Single Nucleotide Polymorphism as Risk Variants in Crohn's Disease. Govaresh 2018, 23, 183-192.

168. Jezernik, G.; Potočnik, U. Comprehensive genetic study of fatty acids helps explain the role of noncoding inflammatory bowel disease associated SNPs and fatty acid metabolism in disease pathogenesis. Prostaglandins Leukot. Essent. Fat. Acids 2018, 130, 1-10. [CrossRef] [PubMed]

169. Liu, R.; Qiao, S.; Shen, W.; Lin, Z.; Guo, Z.; Gong, J.; Ge, Y.; Shui, G.; Li, Y.; Zhu, W. Disturbance of Fatty Acid Desaturation Mediated by FADS2 in Mesenteric Adipocytes Contributes to Chronic Inflammation of Crohn's Disease. Lancet 2019.

170. Ito, Z.; Uchiyama, K.; Odahara, S.; Takami, S.; Saito, K.; Kobayashi, H.; Koido, S.; Kubota, T.; Ohkusa, T.; Saruta, M. Fatty Acids as Useful Serological Markers for Crohn's Disease. Dig. Dis. 2017. [CrossRef]

171. Turner, D.; Zlotkin, S.; Shah, P.; Griffiths, A. Omega 3 fatty acids (fish oil) for maintenance of remission in Crohn's disease. In Cochrane Database of Systematic Reviews; Turner, D., Ed.; John Wiley \& Sons, Ltd.: Chichester, UK, 2007.

172. Costea, I.; MacK, D.R.; Lemaitre, R.N.; Israel, D.; Marcil, V.; Ahmad, A.; Amre, D.K. Interactions between the dietary polyunsaturated fatty acid ratio and genetic factors determine susceptibility to pediatric Crohn's disease. Gastroenterology 2014, 146. [CrossRef]

173. Lindoso, L.; Venkateswaran, S.; Kugathasan, S. PUFAs and IBD. Inflamm. Bowel Dis. 2017, 23, $1905-1907$. [CrossRef] 
174. Naughton, S.S.; Mathai, M.L.; Hryciw, D.H.; McAinch, A.J. Linoleic acid and the pathogenesis of obesity. Prostaglandins Other Lipid Mediat. 2016, 125, 90-99. [CrossRef]

175. Yary, T.; Voutilainen, S.; Tuomainen, T.-P.; Ruusunen, A.; Nurmi, T.; Virtanen, J.K. Omega-6 polyunsaturated fatty acids, serum zinc, delta-5- and delta-6-desaturase activities and incident metabolic syndrome. J. Hum. Nutr. Diet. 2017, 30, 506-514. [CrossRef]

176. Warensjö, E.; Rosell, M.; Hellenius, M.-L.; Vessby, B.; De Faire, U.; Risérus, U. Associations between estimated fatty acid desaturase activities in serum lipids and adipose tissue in humans: links to obesity and insulin resistance. Lipids Health Dis. 2009, 8, 37. [CrossRef] [PubMed]

177. Elbein, S.C.; Kern, P.A.; Rasouli, N.; Yao-Borengasser, A.; Sharma, N.K.; Das, S.K. Global Gene Expression Profiles of Subcutaneous Adipose and Muscle From Glucose-Tolerant, Insulin-Sensitive, and Insulin-Resistant Individuals Matched for BMI. Diabetes 2011, 60, 1019-1029. [CrossRef] [PubMed]

178. Fujita, H.; Hara, K.; Shojima, N.; Horikoshi, M.; Iwata, M.; Hirota, Y.; Tobe, K.; Seino, S.; Kadowaki, T. Variations with modest effects have an important role in the genetic background of type 2 diabetes and diabetes-related traits. J. Hum. Genet. 2012, 57, 776-779. [CrossRef] [PubMed]

179. Dupuis, J. New genetic loci implicated in fasting glucose homeostasis and their impact on type 2 diabetes risk. Nat. Genet. 2010, 42, 105-116.

180. Powell, D.R.; Gay, J.P.; Smith, M.; Wilganowski, N.; Harris, A.; Holland, A.; Reyes, M.; Kirkham, L.; Kirkpatrick, L.L.; Zambrowicz, B.; et al. Fatty acid desaturase 1 knockout mice are lean with improved glycemic control and decreased development of atheromatous plaque. Diabetes. Metab. Syndr. Obes. 2016, 9 , 185-199. [CrossRef]

181. Baugh, S.D.P.; Pabba, P.K.; Barbosa, J.; Coulter, E.; Desai, U.; Gay, J.P.; Gopinathan, S.; Han, Q.; Hari, R.; Kimball, S.D.; et al. Design, synthesis, and in vivo activity of novel inhibitors of delta-5 desaturase for the treatment of metabolic syndrome. Bioorg. Med. Chem. Lett. 2015, 25, 3836-3839. [CrossRef]

182. Yashiro, H.; Takagahara, S.; Tamura, Y.O.; Miyahisa, I.; Matsui, J.; Suzuki, H.; Ikeda, S.; Watanabe, M. A Novel Selective Inhibitor of Delta-5 Desaturase Lowers Insulin Resistance and Reduces Body Weight in Diet-Induced Obese C57BL/6J Mice. PLoS ONE 2016, 11, e0166198. [CrossRef]

183. Stoffel, W.; Hammels, I.; Jenke, B.; Binczek, E.; Schmidt-Soltau, I.; Brodesser, S.; Odenthal, M.; Thevis, M. Obesity resistance and deregulation of lipogenesis in $\triangle 6$-fatty acid desaturase (FADS 2) deficiency. EMBO Rep. 2014, 15, 110-120. [CrossRef]

184. Fedor, D.; Kelley, D.S. Prevention of insulin resistance by n-3 polyunsaturated fatty acids. Curr. Opin. Clin. Nutr. Metab. Care 2009, 12, 138-146. [CrossRef]

185. Cavaliere, G.; Trinchese, G.; Bergamo, P.; De Filippo, C.; Mattace Raso, G.; Gifuni, G.; Putti, R.; Moni, B.H.; Canani, R.B.; Meli, R.; et al. Polyunsaturated Fatty Acids Attenuate Diet Induced Obesity and Insulin Resistance, Modulating Mitochondrial Respiratory Uncoupling in Rat Skeletal Muscle. PLoS ONE 2016, 11, e0149033. [CrossRef]

186. Wanders, A.J.; Blom, W.A.M.; Zock, P.L.; Geleijnse, J.M.; Brouwer, I.A.; Alssema, M. Plant-derived polyunsaturated fatty acids and markers of glucose metabolism and insulin resistance: A meta-analysis of randomized controlled feeding trials. BMJ Open Diabetes Res. Care 2019, 7. [CrossRef] [PubMed]

187. Jump, D.B.; Botolin, D.; Wang, Y.; Xu, J.; Christian, B.; Demeure, O. Fatty Acid Regulation of Hepatic Gene Transcription. J. Nutr. 2005, 135, 2503-2506. [CrossRef] [PubMed]

188. Schenk, S.; Saberi, M.; Olefsky, J.M. Insulin sensitivity: Modulation by nutrients and inflammation. J. Clin. Investig. 2008, 118, 2992-3002. [CrossRef] [PubMed]

189. Pérez-Matute, P.; Pérez-Echarri, N.; Martínez, J.A.; Marti, A.; Moreno-Aliaga, M.J. Eicosapentaenoic acid actions on adiposity and insulin resistance in control and high-fat-fed rats:Rrole of apoptosis, adiponectinand tumour necrosis factor- $\alpha$. Br. J. Nutr. 2007, 97, 389-398. [CrossRef] [PubMed]

190. Spahis, S.; Alvarez, F.; Dubois, J.; Ahmed, N.; Peretti, N.; Levy, E. Plasma fatty acid composition in French-Canadian children with non-alcoholic fatty liver disease: Effect of n-3 PUFA supplementation. Prostaglandins Leukot. Essent. Fat. Acids 2015, 99, 25-34. [CrossRef] [PubMed]

191. Feng, R.; Luo, C.; Li, C.; Du, S.; Okekunle, A.P.; Li, Y.; Chen, Y.; Zi, T.; Niu, Y. Free fatty acids profile among lean, overweight and obese non-alcoholic fatty liver disease patients: A case - Control study. Lipids Health Dis. 2017, 16. [CrossRef] 
192. Walle, P.; Takkunen, M.; Männistö, V.; Vaittinen, M.; Lankinen, M.; Kärjä, V.; Käkelä, P.; Ågren, J.; Tiainen, M.; Schwab, U.; et al. Fatty acid metabolism is altered in non-alcoholic steatohepatitis independent of obesity. Metabolism 2016, 65, 655-666. [CrossRef]

193. Walle, P.; Männistö, V.; de Mello, V.D.; Vaittinen, M.; Perfilyev, A.; Hanhineva, K.; Ling, C.; Pihlajamäki, J. Liver DNA methylation of FADS2 associates with FADS2 genotype. Clin. Epigenetics 2019, 11, 10. [CrossRef]

194. Puri, P.; Wiest, M.M.; Cheung, O.; Mirshahi, F.; Sargeant, C.; Min, H.-K.; Contos, M.J.; Sterling, R.K.; Fuchs, M.; Zhou, H.; et al. The plasma lipidomic signature of nonalcoholic steatohepatitis. Hepatology 2009, 50, 1827-1838. [CrossRef]

195. Nobili, V.; Alisi, A.; Liu, Z.; Liang, T.; Crudele, A.; Raponi, M.; Lin, J.; Chalasani, N.P.; Liu, W. In a pilot study, reduced fatty acid desaturase 1 function was associated with nonalcoholic fatty liver disease and response to treatment in children. Pediatr. Res. 2018, 84, 696-703. [CrossRef]

196. He, Z.; Zhang, R.; Jiang, F.; Zhang, H.; Zhao, A.; Xu, B.; Jin, L.; Wang, T.; Jia, W.; Jia, W.; et al. FADS1-FADS2 genetic polymorphisms are associated with fatty acid metabolism through changes in DNA methylation and gene expression. Clin. Epigenetics 2018, 10, 113. [CrossRef] [PubMed]

197. Younossi, Z.; Anstee, Q.M.; Marietti, M.; Hardy, T.; Henry, L.; Eslam, M.; George, J.; Bugianesi, E. Global burden of NAFLD and NASH: trends, predictions, risk factors and prevention. Nat. Rev. Gastroenterol. Hepatol. 2018, 15, 11-20. [CrossRef] [PubMed]

198. Wong, V.W.-S.; Adams, L.A.; de Lédinghen, V.; Wong, G.L.-H.; Sookoian, S. Noninvasive biomarkers in NAFLD and NASH - current progress and future promise. Nat. Rev. Gastroenterol. Hepatol. 2018, 15, 461-478. [CrossRef] [PubMed]

199. Xu, Y.; Zhao, Z.; Liu, S.; Xiao, Y.; Miao, M.; Dong, Q.; Xin, Y. Association of Nonalcoholic Fatty Liver Disease and Coronary Artery Disease with FADS2 rs3834458 Gene Polymorphism in the Chinese Han Population. Gastroenterol. Res. Pract. 2019. [CrossRef] [PubMed]

200. Röhrig, F.; Schulze, A. Fatty acid synthase The multifaceted roles of fatty acid synthesis in cancer. Nat. Rev. Cancer 2016.

201. Vriens, K.; Christen, S.; Parik, S.; Broekaert, D.; Yoshinaga, K.; Talebi, A.; Dehairs, J.; Escalona-Noguero, C.; Schmieder, R.; Cornfield, T.; et al. Evidence for an alternative fatty acid desaturation pathway increasing cancer plasticity. Nature 2019, 566, 403-406. [CrossRef]

202. Zhang, B.; Jia, W.H.; Matsuda, K.; Kweon, S.S.; Matsuo, K.; Xiang, Y.B.; Shin, A.; Jee, S.H.; Kim, D.H.; Cai, Q.; et al. Large-scale genetic study in east Asians identifies six new loci associated with colorectal cancer risk. Nat. Genet. 2014, 46, 533-542. [CrossRef]

203. Pender-Cudlip, M.C.; Krag, K.J.; Martini, D.; Yu, J.; Guidi, A.; Skinner, S.S.; Zhang, Y.; Qu, X.; He, C.; Xu, Y.; et al. Delta-6-desaturase activity and arachidonic acid synthesis are increased in human breast cancer tissue. Cancer Sci. 2013, 104, 760-764. [CrossRef]

204. Konstorum, A.; Lynch, M.L.; Torti, S.V.; Torti, F.M.; Laubenbacher, R.C. A Systems Biology Approach to Understanding the Pathophysiology of High-Grade Serous Ovarian Cancer: Focus on Iron and Fatty Acid Metabolism. Omi. A J. Integr. Biol. 2018, 22, 502-513. [CrossRef]

205. Zhao, H.; Langerød, A.; Ji, Y.; Nowels, K.W.; Nesland, J.M.; Tibshirani, R.; Bukholm, I.K.; Kåresen, R.; Botstein, D.; Børresen-Dale, A.-L.; et al. Different Gene Expression Patterns in Invasive Lobular and Ductal Carcinomas of the Breast. Mol. Biol. Cell 2004, 15, 2523-2536. [CrossRef]

206. He, C.; Qu, X.; Wan, J.; Rong, R.; Huang, L.; Cai, C.; Zhou, K.; Gu, Y.; Qian, S.Y.; Kang, J.X. Inhibiting Delta-6 Desaturase Activity Suppresses Tumor Growth in Mice. PLoS ONE 2012, 7, e47567. [CrossRef] [PubMed]

207. Faubert, B.; Li, K.Y.; Cai, L.; Hensley, C.T.; Kim, J.; Zacharias, L.G.; Yang, C.; Do, Q.N.; Doucette, S.; Burguete, D.; et al. Lactate Metabolism in Human Lung Tumors. Cell 2017, 171, 358-371.e9. [CrossRef] [PubMed]

208. Xie, L.; Innis, S.M. Genetic Variants of the FADS1 FADS2 Gene Cluster Are Associated with Altered (n-6) and (n-3) Essential Fatty Acids in Plasma and Erythrocyte Phospholipids in Women during Pregnancy and in Breast Milk during Lactation. J. Nutr. 2008, 138, 2222-2228. [CrossRef] [PubMed]

209. Muc, M.; Kreiner-Møller, E.; Larsen, J.; Madura; Birch, S.; Pedersen, S.; Bisgaard, H.; Lauritzen, L. Maternal fatty acid desaturase genotype correlates with infant immune responses at 6 months. Br. J. Nutr. 2015, 114, 891-898. [CrossRef] [PubMed]

210. Ding, Z.; Liu, G.-L.; Li, X.; Chen, X.-Y.; Wu, Y.-X.; Cui, C.-C.; Zhang, X.; Yang, G.; Xie, L. Association of polyunsaturated fatty acids in breast milk with fatty acid desaturase gene polymorphisms among Chinese lactating mothers. Prostaglandins, Leukot. Essent. Fat. Acids 2016, 109, 66-71. [CrossRef] 
211. Caspi, A.; Williams, B.; Kim-Cohen, J.; Craig, I.W.; Milne, B.J.; Poulton, R.; Schalkwyk, L.C.; Taylor, A.; Werts, H.; Moffitt, T.E. Moderation of breastfeeding effects on the IQ by genetic variation in fatty acid metabolism. Proc. Natl. Acad. Sci. USA 2007, 104, 18860-18865. [CrossRef]

212. Gould, J.F.; Smithers, L.G. Prenatal n-3 Long-Chain Polyunsaturated Fatty Acids and Children's Executive Functions. Omega Fat. Acids Brain Neurol. Heal. 2019, 83-105.

213. Badiou, S.; Tuaillon, E.; Viljoen, J.; Escudié, J.B.; Cristol, J.P.; Newell, M.L.; Van de Perre, P.; Neveu, D. Association between breast milk fatty acids and HIV-1 transmission through breastfeeding. Prostaglandins, Leukot. Essent. Fat. Acids 2016, 105, 35-42. [CrossRef]

214. Andersen, K.R.; Harsløf, L.B.S.; Schnurr, T.M.; Hansen, T.; Hellgren, L.; Michaelsen, K.F.; Lauritzen, L. A study of associations between early DHA status and fatty acid desaturase (FADS) SNP and developmental outcomes in children of obese mothers. Br. J. Nutr. 2017, 117, 278-286. [CrossRef]

215. Brookes, K.J.; Chen, W.; Xu, X.; Taylor, E.; Asherson, P. Association of Fatty Acid Desaturase Genes with Attention-Deficit/Hyperactivity Disorder. Biol. Psychiatry 2006, 60, 1053-1061. [CrossRef]

216. Nishida, I.; Murata, N. Chilling Sensitivity In Plants And Cyanobacteria: The Crucial Contribution of Membrane Lipids. Annu. Rev. Plant Physiol. Plant Mol. Biol. 1996, 47, 541-568. [CrossRef] [PubMed]

217. Healy-Stoffel, M.; Levant, B. N-3 (Omega-3) Fatty Acids: Effects on Brain Dopamine Systems and Potential Role in the Etiology and Treatment of Neuropsychiatric Disorders. CNS Neurol. Disord. Drug Targets 2018, 17, 216-232. [CrossRef] [PubMed]

218. Cao, B.; Wang, D.; Sun, X.; Yan, J.; Ren, B.; Lu, Q.; Liu, Y.; Zeng, J.; Huang, N.; Xie, Q.; et al. Alterations of eicosanoids and related mediators in patients with schizophrenia meta-analysis View project Alterations of eicosanoids and related mediators in patients with schizophrenia. J. Psychiatr. Res. 2018, 102, 168-178.

219. Liu, Y.; McNamara, R.K. Elevated Delta-6 desaturase (FADS2) gene expression in the prefrontal cortex of patients with bipolar disorder. J. Psychiatr. Res. 2011, 45, 269-272. [CrossRef] [PubMed]

220. Liu, Y.; Jandacek, R.; Rider, T.; Tso, P.; McNamara, R.K. Elevated delta-6 desaturase (FADS2) expression in the postmortem prefrontal cortex of schizophrenic patients: Relationship with fatty acid composition. Schizophr. Res. 2009, 109, 113-120. [CrossRef] [PubMed]

221. Yao, J.K.; Leonard, S.; Reddy, R.D. Membrane phospholipid abnormalities in postmortem brains from schizophrenic patients. Schizophr. Res. 2000, 42, 7-17. [CrossRef]

222. Maekawa, M.; Watanabe, A.; Iwayama, Y.; Kimura, T.; Hamazaki, K.; Balan, S.; Ohba, H.; Hisano, Y.; Nozaki, Y.; Ohnishi, T.; et al. Polyunsaturated fatty acid deficiency during neurodevelopment in mice models the prodromal state of schizophrenia through epigenetic changes in nuclear receptor genes. Transl. Psychiatry 2017, 7. [CrossRef]

223. Mercuri, O.; de Tomás, M.E.; Itarte, H. Prenatal protein depletion and $\Delta 9, \Delta 6$ and $\Delta 5$ desaturases in the rat. Lipids 1979, 14, 822-825. [CrossRef]

224. de Tomás, M.E.; Mercuri, O.; Rodrigo, A. Effects of Dietary Protein and EFA Deficiency on Liver $\Delta 5, \Delta 6$ and $\Delta 9$ Desaturase Activities in the Early Developing Rat. J. Nutr. 1980, 110, 595-599. [CrossRef]

225. Pawełczyk, T.; Grancow-Grabka, M.; Kotlicka-Antczak, M.; Trafalska, E.; Pawełczyk, A. A randomized controlled study of the efficacy of six-month supplementation with concentrated fish oil rich in omega-3 polyunsaturated fatty acids in first episode schizophrenia. J. Psychiatr. Res. 2016, 73, 34-44. [CrossRef]

226. Bošković, M.; Vovk, T.; Koprivšek, J.; Plesničar, B.K.; Grabnar, I. Vitamin E and essential polyunsaturated fatty acids supplementation in schizophrenia patients treated with haloperidol. Nutr. Neurosci. 2016, 19, 156-161. [CrossRef] [PubMed]

227. Bentsen, H.; Osnes, K.; Refsum, H.; Solberg, D.K.; Bøhmer, T. A randomized placebo-controlled trial of an omega-3 fatty acid and vitamins E\&plus;C in schizophrenia. Transl. Psychiatry 2013, 3.

(C) 2020 by the authors. Licensee MDPI, Basel, Switzerland. This article is an open access article distributed under the terms and conditions of the Creative Commons Attribution (CC BY) license (http://creativecommons.org/licenses/by/4.0/). 